\title{
Tectonics and gravitational phenomena (Nanos, Slovenia)
}

\author{
Tektonika in gravitacijski pojavi (Nanos, Slovenija) \\ Ladislav PLACER ${ }^{1}$, Andrej MIHEVC M Igor RIŽNAR $^{3}$ \\ ${ }^{1}$ Geološki zavod Slovenije, Dimičeva ul. 14, SI-1000 Ljubljana, Slovenija; e-mail: ladislav.placer@telemach.net \\ ${ }^{2}$ Inštitut za raziskovanje krasa, Titov trg 2, SI-6230 Postojna, Slovenija; e-mail: andrej.mihevc@zrc-sazu.si \\ ${ }^{3}$ Geološke ekspertize Igor Rižnar s. p., SI-1000 Ljubljana, Slovenija; e-mail: igor.riznar@telemach.net
}

Prejeto / Received 22.1. 2021; Sprejeto / Accepted 1. 7. 2021; Objavljeno na spletu / Published online 19. 7. 2021

Key words: gravitational phenomena, geomorphology, Istra Pushed Area, Nanos, Hrušica, razdol, Adria Ključne besede: gravitacijski pojavi, geomorfologija, istrsko potisno območje, Nanos, Hrušica, razdol, Adria

\begin{abstract}
The Istra Pushed Area is a specifically deformed territory of the northwestern part of the External Dinarides. It formed due to the movement of the Istra block as part of the Adriatic Microplate (Adria) towards the Dinarides since the middle Miocene. The movement of the Istra block caused hereditary shifts along the old dislocations dating back to the early formation stage of the formation of the Dinarides at the end of the Eocene and their deformation. These deformations are reflected also in certain extreme gravitational phenomena along the boundary between the External Dinaric Imbricated Belt and the External Dinaric Thrust Belt, where Mesozoic carbonates are thrusted upon the Cenozoic flysch. The boundary zone between these two belts connects the Trnovo, Hrušica and Snežnik Thrust Fronts. Four specific gravitational phenomena that occurred in this boundary zone are presented here, as they are remarkable in terms of their size: Črna griža (Trnovo Nappe), Suhi vrh (Hrušica Nappe), Petelinje mlake and Ilirska Bistrica (both from the Snežnik Nappe). The phenomena at Suhi vrh is described in detail herein.
\end{abstract}

\section{Izvleček}

Istrsko potisno območje je specifično deformirano ozemlje severozahodnega dela Zunanjih Dinaridov. Nastalo je zaradi pomikanja istrskega bloka, ki je del Jadranske mikroplošče (Adria), proti Dinaridom. To se dogaja od srede miocena naprej. Pomikanje istrskega bloka je povzročilo nasledstvene premike po starih dislokacijah iz zaključka prvega obdobja nastajanja Dinaridov konec eocena in njihovo deformacijo. Te deformacije se odražajo tudi v ekstremnih gravitacijskih pojavih na meji med Zunanjedinarskim naluskanim pasom in Zunanjedinarskim narivnim pasom, kjer so mezozojski karbonati narinjeni na kenozojski fliš. Omenjeni mejni pas povezuje čela krovnih narivov Trnovskega, Hrušiškega in Snežniškega pokrova. V članku so prikazani štirje specifični gravitacijski pojavi, ki so izjemni po velikosti: Črni školj (Trnovski pokrov), Suhi vrh (Hrušiški pokrov) ter Petelinje mlake in Ilirska Bistrica (oba Snežniški pokrov). Natančneje je opisan pojav Suhi vrh.

\section{Introduction}

A formal boundary between the Adriatic Microplate (Adria) and the Dinarides in the NW Dinarides after Schmidt et al. (2008) runs along the External Dinarides thrust boundary in the Istra and Gulf of Trieste hinterland (Fig. 1). As the Adria rotates in a counterclockwise direction obliquely to the Dinarides (Weber et al., 2006) the movements against the Dinarides are released along two components: orthogonally (pushing, and con-

\section{Uvod}

Formalna meja med Jadransko mikroploščo (Adria) in Dinaridi poteka po Schmid-u in sodelavcih (2008) po narivni meji Zunanjih Dinaridov, ki se v severozahodnih Dinaridih nahaja v zaledju Istre in Tržaškega zaliva (sl. 1). Adria rotira v nasprotni smeri urinega kazalca poševno na Dinaride (Weber et al., 2006), zato se njeni pomiki nasproti Dinaridom sproščajo po dveh komponentah, pravokotno nanje (potiskanje in 


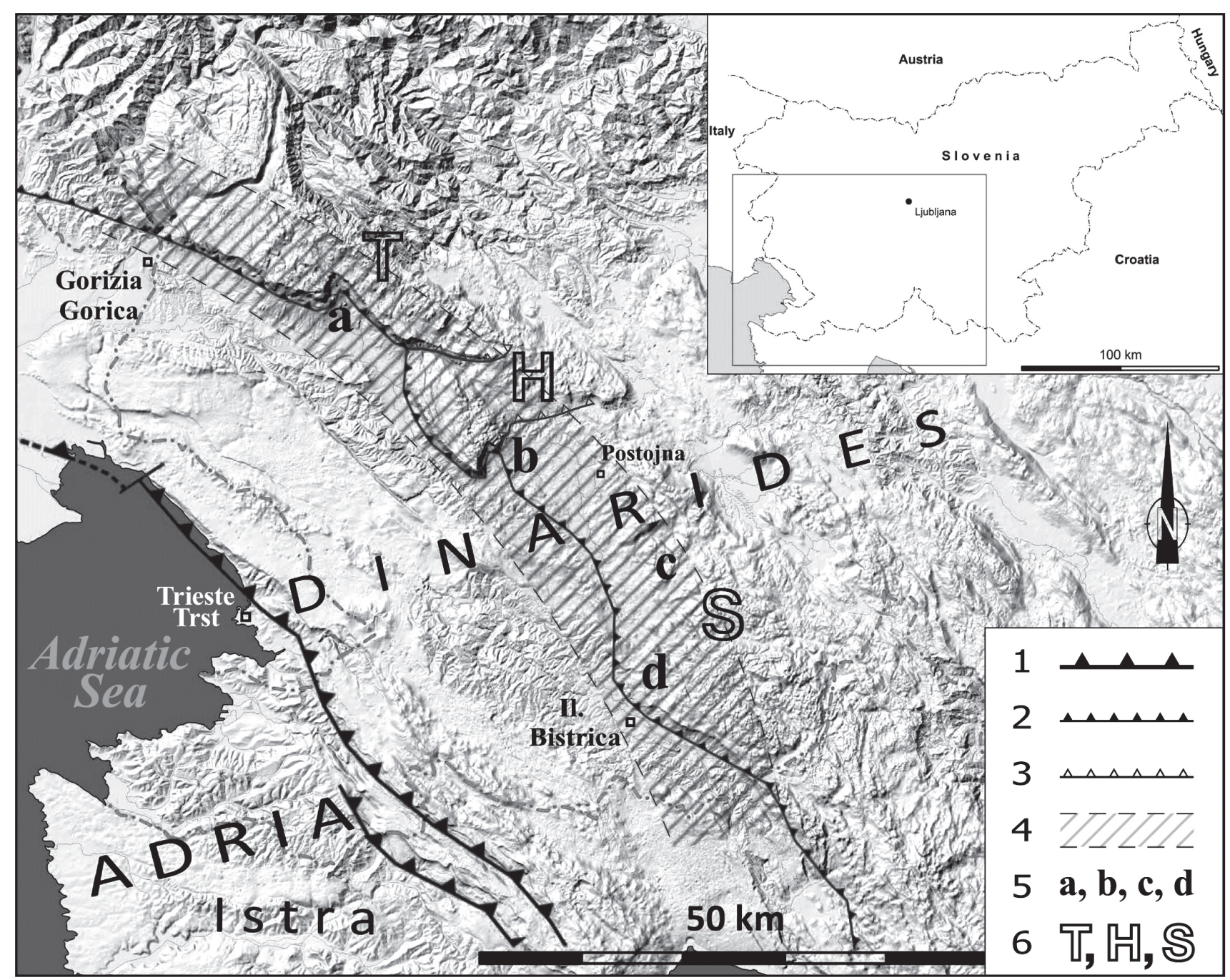

Fig. 1. The Adria (sensu stricto) and the northwestern Dinarides boundary zone. Belt of large gravitational phenomena.

Sl. 1. Mejno območje Adrie (sensu stricto) in severozahodnih Dinaridov. Pas velikih gravitacijskih pojavov.

1 External Dinarides boundary / meja Zunanjih Dinaridov

2 External Dinaric Thrust Belt boundary / meja Zunanjedinarskega narivnega pasu

3 Nappe boundary / meja pokrova

4 Belt of large gravitational phenomena / pas velikih gravitacijskih pojavov

5 Outstanding gravitaitional phenomena / izjemni gravitacijski pojavi: a - Črni školj, b - Suhi vrh, c - Petelinje mlake, d - Ilirska Bistrica

6 T - Trnovo Nappe / Trnovski pokrov, H - Hrušica Nappe / Hrušiški pokrov, S - Snežnik Nappe / Snežniški pokrov

sequential folding and underthrusting), and parallel to the Dinarides (via right lateral strike slip along subvertical faults) (Placer et al., 2010). Istra is a structural block within the Adria and moves against the Dinarides faster than the blocks SE of it. As a consequence, the External Dinarides in the Istra hinterland between the Southern Alps and the Velebit are cambered (bent) towards the NE. This bent part of the External Dinarides is called the Istra Pushed Area (Placer, 2010).

Formally, the assumed movement of the Istra against the Dinarides is evidenced by local block rotation in the Čičarija in the Istra hinterland by palaeomagnetic analysis of the cave sediments there (Vrabec et al., 2018). Using said analysis, the theory of the existence of the Istra Pushed Area posledično gubanje ter podrivanje) in vzporedno z njimi (desno zmikanje ob subvertikalnih prelomih) (Placer et al., 2010). Istra je blok v okviru Adrie, ki se proti Dinaridom premika hitreje od blokov jugovzhodno od tod, zato so Zunanji Dinaridi v njenem zaledju med Južnimi Alpami in Velebitom usločeni proti severovzhodu. Ta predel Zunanjih Dinaridov se v strukturnem smislu imenuje istrsko potisno območje (Placer et al., 2010).

Domneva o premikanju Istre proti Dinaridom je bila formalno dokazana $\mathrm{z}$ lokalno rotacijo blokov v Čičariji v zaledju Istre, dokaz pa temelji na analizi starosti in paleomagnetizma jamskih sedimentov (Vrabec et al., 2018). S tem je bila potrjena teorija o obstoju istrskega potisnega ob- 
was confirmed and forms the basis of the study of the structures within the area. The principal feature within the Istra Pushed Area is the deformation of older brittle and ductile deformation. Block rotation analysis revealed a correlation between the local rotation and bending of the Čičarija Imbricate Structure. Regional data shows that other Dinaric structures within the Istra Pushed Area such as the Trieste-Komen Anticlinorium and the Vipava Synclinorium are also bent, so correlation between the surface structure and the local block rotation is expected there as well.

Istra's movement against the Dinarides is an uneven but continuous process that has been taking place since at least $5 \mathrm{Ma}$, which is the oldest age of the cave sediments analyzed. However, this age reflects the method range rather than the absolute duration of the described motion (Vrabec et al., 2018). The process started already in the Middle or even Lower Miocene; [and regarding the GPS measurements (Weber et al., 2006) takes place even nowadays], which is best reflected in the gravitational processes at work on the morphologically exposed boundary of the External Dinaric nappe thrusts, formally in the fore part of the External Dinaric Thrust Belt.

\section{Belt (zone) of large gravitational phenomena}

The boundary zone along the External Dinaric Thrust Belt comprised of the Trnovo, Hrušica and Snežnik Thrust Fronts, is particularly outstanding in the Istra Pushed Area (Fig. 1). The instability of the thrust fronts due to Mz carbonates thrust upon the siliciclastic flysch best characterise this belt. Local post-tectonic uplift and the denuding of the flysch footwalls have also played an important part in said development. These processes led to a significant geomorphologic step with a highly elevated risk of landslide (Komac \& Ribičič, 2008); and at the same time came to constitute a highly attractive subject of research (Popit, 2016; 2017; Verbovšek et al., 2017; 2019). The thrust front zone is referred to as a "belt of large gravitational phenomena" due to the intense and diverse gravitational activity there. Its width is determined by the extent of these phenomena, where a wide variety of mass wasting forms is recognized, such as translational (planar) and rotational slides, rockfalls, rockslides and mass flows. Longer-term tectonic and denudational activity is reflected in the overlapping of multiple superimposed landslides following each other in different temporal increments. Peculiar "gravitational duplexes" (as they could be called) are the most interesting among these močja in postavljeno je bilo stvarno izhodišče za študij deformacij v njem.

Glavna značilnost istrskega potisnega območja so deformacije starejših plikativnih in disjunktivnih struktur. Analiza rotacije blokov v Čičariji je pokazala na soglasje med lokalno rotacijo in bočno usločenostjo Čičarijskega antiklinorija. Regionalni podatki kažejo, da so bočno usločene tudi druge dinarske strukture istrskega potisnega območja, npr. Tržaško-Komenski antiklinorij in Vipavski sinklinorij, zato tudi tu pričakujemo soglasje med površinsko strukturo in lokalno rotacijo blokov.

Premikanje Istre proti Dinaridom je neenakomeren, vendar kontinuiran proces, ki je starejši od 5 milijonov let. $\mathrm{Na}$ to kaže najvišja starost analiziranih jamskih sedimentov v Čičariji (Vrabec et al., 2018). Pričetek tega procesa pa sega v srednji ali celo v spodnji miocen in je glede na meritve GPS (Weber et al., 2010), dejaven še danes. Slednje se najlepše kaže v gravitacijskih procesih na morfološko izpostavljeni meji Zunanjedinarskih krovnih narivov, formalno v čelnem delu Zunanjedinarskega narivnega pasu.

\section{Pas velikih gravitacijskih pojavov}

Znotraj istrskega potisnega območja posebej izstopa mejni del Zunanjedinarskega narivnega pasu, ki ga sestavljajo čela Trnovskega, Hrušiškega in Snežniškega pokrova (prej Snežniška narivna gruda) (sl. 1). Glavna značilnost tega pasu je nestabilnost čela krovnih enot, ki je posledica nariva mezozojskih karbonatov na siliciklastične flišne plasti. Poleg tega je imelo pomembno vlogo še krajevno omejeno postnarivno tektonsko dviganje in denudacija fliša talninskih krovnih enot. Ti procesi so pripeljali do izoblikovanja geomorfološke stopnje, ki predstavlja izrazito območje tveganja za proženje zemeljskih plazov (Komac \& Ribičič, 2008) in hkrati privlačno območje njihovega proučevanja (Popit, 2016, 2017; Verbovšek et al., 2017, 2019). Zaradi raznolike in intenzivne gravitacijske dejavnosti, smo čelni rob opisanih krovnih enot poimenovali »pas velikih gravitacijskih pojavov«. Njegovo širino določa vplivno območje zdrsov. Tu je nastala cela vrsta gravitacijskih pojavov kot so planarni in rotacijski plazovi, odlomi, blokovni zdrsi in masni tokovi. $\mathrm{Na}$ daljšo tektonsko in denudacijsko aktivnost kaže sožitje fosilnih in recentnih plazov, od katerih so najbolj zanimivi svojevrstni "gravitacijski dupleksi« kot bi lahko imenovali plazove $\mathrm{v}$ nadstropjih, ki so 
"multistorey" landslides. Individual superimposed mass wasting events (phenomena) may also differ from among each other in terms of their various genetic types, like the rotational fossil Mala Gora landslide superimposed by an active translational Slano blato landslide (Placer et al., 2008), and a rotational fossil Reševnik landslide superimposed by an active translational Razdrto landslide (Placer, 2006).

The gravitational phenomena here are divided into two distinctive areas according to the prevailing mechanisms at work: the Trnovo and Hrušica Nappes Thrust Fronts on one side, and the Snežnik Nappe Thrust Front on the other. In the first case, large gravitational phenomena occur between Vitovlje above Šempas in the Vipava valley, and at Razdrto, in the western part of the Postojna basin. Two slopes stand out here, running parallel to the NNE-SSW trending regional fractures and hence close to the NW-SE trending thrust plane. The two areas share identical geomorphologic characteristics: the eastern slope of the Caven high karst plane (plateau) between Mt. Črni školj (1180 m a.s.l.), Mt. Mali Modrasovec (1306 m a.s.l.) and Mt. Mala Gora (1032 m a.s.l.)

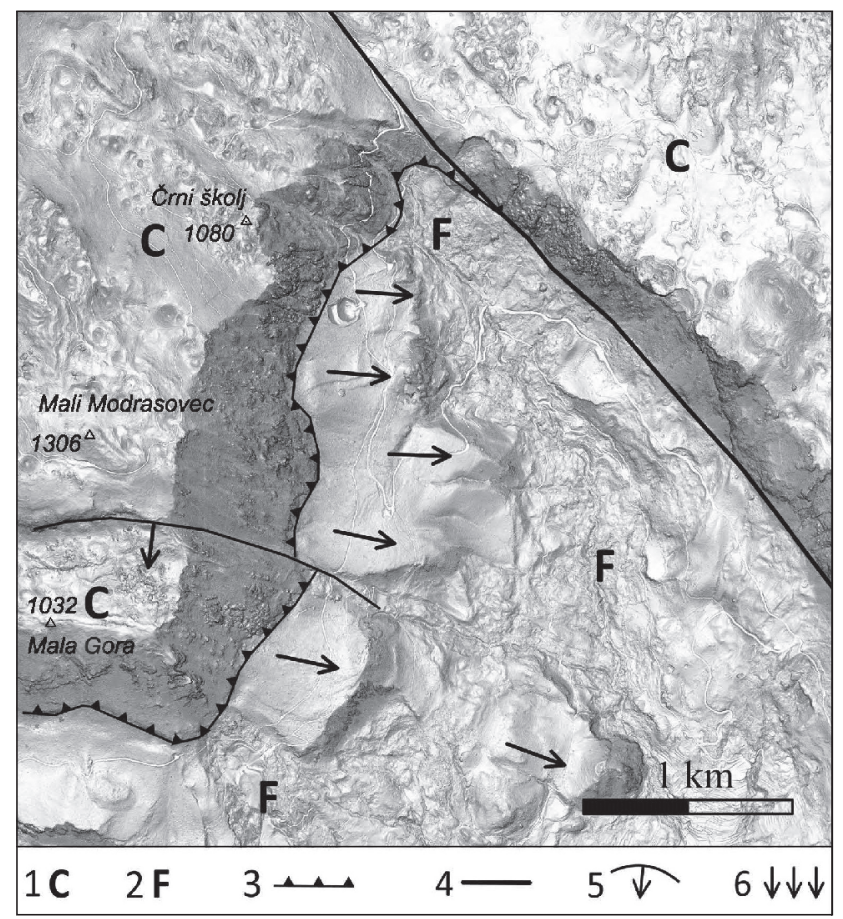

Fig. 2. Črni školj landslide area.

Sl. 2. Plazišče Crni školj.

1 C - Trnovo Nappe carbonates / karbonati Trnovskega pokrova

2 F - Flysch of the External Dinaric Imbricated Belt / fliš Zunanjedinarskega naluskanega pasu

3 Trnovo Nappe boundary /meja Trnovskega pokrova

4 Podgora (former Predjama) fault / Podgorski (prej

Predjamski) prelom

5 Mala Gora rotational landslide / rotacijski plaz Mala Gora 6 Črni školj landslide area / plazišče Črni školj nastajali zaporedoma v krajših ali daljših časovnih presledkih. Ti so lahko genetsko istorodni ali raznorodni; taka večja pojava sta npr. rotacijski fosilni plaz Mala Gora na katerem leži aktivni planarni zemeljski plaz Slano blato (Placer et al., 2008) in rotacijski fosilni plaz Reševnik na katerem leži aktivni planarni zemeljski plaz Razdrto (Placer, 2006).

Gravitacijski pojavi obravnavanega pasu se po prevladujočem mehanizmu delijo na dve območji, na eni strani sta čeli Trnovskega in Hrušiškega pokrova, na drugi čelo Snežniškega pokrova. V prvem primeru nastopajo veliki gravitacijski pojavi med Vitovljami nad Šempasom v Vipavski dolini in Razdrtim v zahodnem delu Postojnske kotline. Tu izstopata dve pobočji, ki ležita v smeri prevladujočih regionalnih razpok SSW-NNE, torej blizu smeri narivanja SW-NE, $\mathrm{v}$ katerih je določljiva lega narivne ploskve. Območji imata identične geomorfološke značilnosti, pri Trnovskem pokrovu je to vzhodno pobočje visoke kraške planote Čaven med Črnim školjem (1080 m), Malim Modrasovcem (1306 m) in Malo Goro (1032 m) (sl. 1, a; sl. 2), pri Hrušiškem pokrovu jugovzhodno pobočje visoke

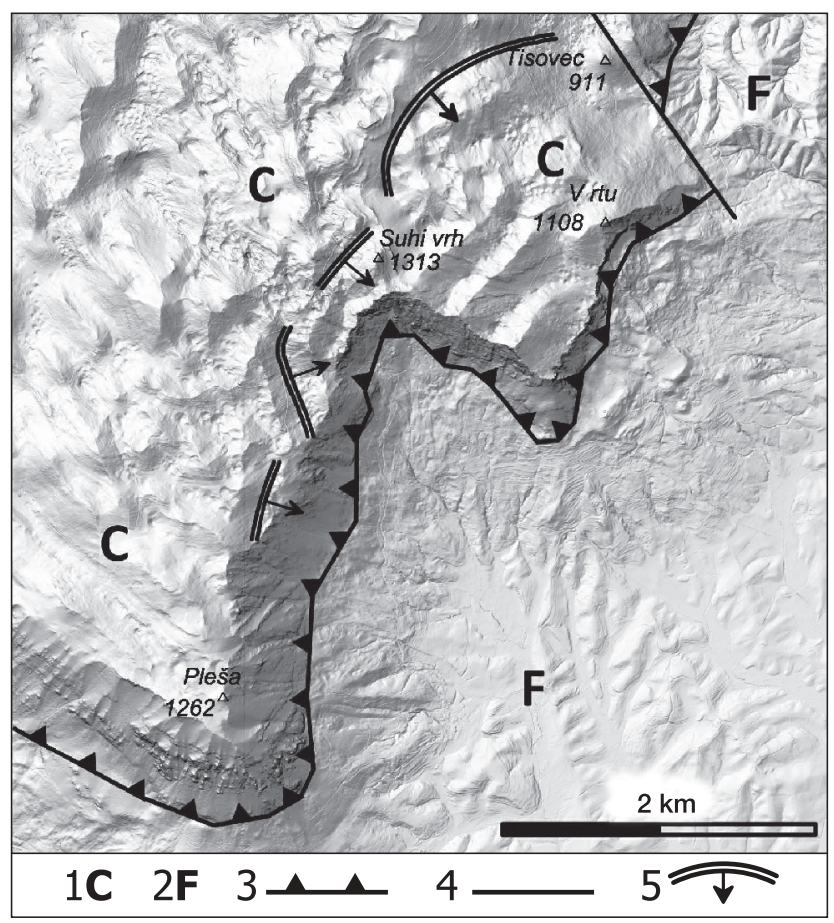

Fig. 3. Suhi vrh gravitational phenomena.

Sl. 3. Gravitacijski pojav Suhi vrh.

$1 \mathrm{C}$-Hrušica Nappe carbonates / karbonati Hrušiškega pokrova

2 F - Flysch of the Snežnik Nappe and of the External Dinaric Imbricated Belt / fliš Snežniškega pokrova in Zunanjedinarskega naluskanega pasu

3 Hrušica Nappe boundary / meja Hrušiškega pokrova 4 Fault / prelom

5 Suhi vrh gravitational area / gravitacijsko območje Suhi vrh 


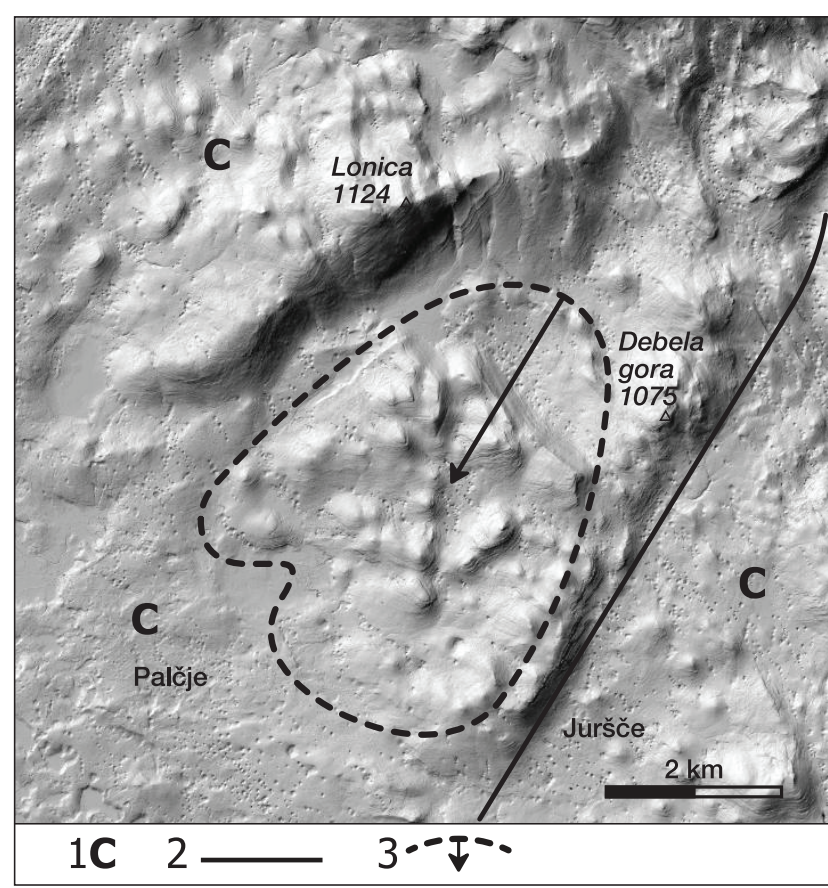

Fig. 4. Petelinje mlake rotational landslide.

Sl. 4. Rotacijski plaz Petelinje mlake.

1 C - Snežnik Nappe carbonates / karbonati Snežniškega pokrova

2 Juršče fault / Jurški prelom

3 Landslide mass / masa plazu

(Fig. 1, a; Fig. 2) in the case of the Trnovo Nappe, and the SE slope of the Nanos high karst plane (plateau) between Mt. Pleša (1262 m a.s.l.) and Mt. V rtu (1108 m a.s.1.) (Fig. 1, b; Fig. 3).

In the thrust front of the Snežnik Nappe, gravitational phenomena comparable to those in the Trnovo and Hrušica Nappes Thrust Fronts are only found SE of Ilirska Bistrica. Two outstanding phenomena are present in the intermediate area between Razdrto and Ilirska Bistrica: an inferred fossil rotational landslide at Petelinje mlake (Fig. 1, c; Fig. 4), and the Ilirska Bistrica fossil rotational landslide (Fig. 1, d; Fig. 5), both formed under particularly specific conditions. Except for these two phenomena, the Snežnik Nappe Thrust Front does not exhibit any other large gravitational features, as the Snežnik Nappe flysch is thrust upon the flysch of the External Dinaric Imbricated Belt in the eastern part of the Postojna basin, where the relief between the two nappes is levelled due to the absence of carbonates there. Due south-east, between Hruševje and Šembije, at the edge of the Ilirska Bistrica fossil landslide, the geomorphological step is not yet high enough to pose a gravitational risk.

A brief, informative introduction of the tectonic environment for the four outstanding cases present in the belt of the large gravitational phenomena is necessary in order to understand the described differences in the geomorphology and

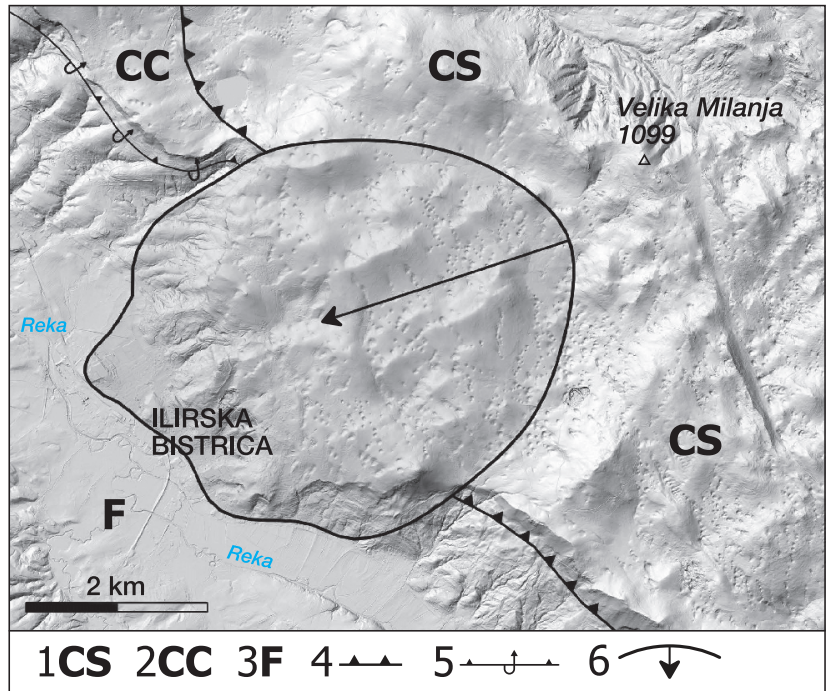

Fig. 5. Ilirska Bistrica rotational landslide. Sl. 5. Rotacijski plaz Ilirska Bistrica.

1 CS - Snežnik Nappe carbonates / karbonati Snežniškega pokrova

2 CC - Carbonates of the External Dinaric Imbricated Belt / karbonati Zunanjedinarskga naluskanega pasu

3 F - Flysch of the External Dinaric Imbricated Belt / fliš Zunanjedinarskega naluskanega pasu

4 Snežnik Nappe boundary / meja Snežniškega pokrova

5 Tectonized boundary of the inverse beds within the External Dinaric Imbricated Belt / tektonizirana meja inverznih plasti znotraj Zunanjedinarskega naluskanega pasu

6 Landslide mass / masa plazu

kraške planote Nanos med Plešo (1262 m) in vrhom V rtu (1108 m) (sl. 1, b; sl. 3).

V čelu Snežniškega pokrova nastopajo gravitacijski pojavi, ki jih je mogoče primerjati s tistimi v Trnovskem in Hrušiškem pokrovu, šele jugovzhodno od Ilirske Bistrice. Na vmesnem prostoru med Razdrtim in Ilirsko Bistrico nastopata dva izjemna pojava, domnevni fosilni rotacijski plaz Petelinje mlake (sl. 1, c; sl. 4) in ilirskobistriški fosilni rotacijski plaz (sl. 1, d; sl. 5), ki sta nastala pri specifičnih pogojih. Izven teh dveh pojavov so razmere umirjene, tu je na zahodni strani Postojnske kotline fliš Snežniškega pokrova narinjen na fliš Zunanjedinarskega naluskanega pasu, zaradi česar je površje obeh krovnih enot uravnano na skupni nivo, na jugovzhodu med Hruševjem in Šembijami na robu velikega ilirskobistriškega fosilnega plazu, pa geomorfološki prag v čelu Snežniškega pokrova še ni tako visok, da bi bil gravitacijsko ogrožen.

Za razumevanje opisanih razlik $\mathrm{v}$ geomorfologiji in gravitacijskih pojavih, je potrebno vsaj informativno predstaviti tektonsko okolje štirih izstopajočih primerov v pasu velikih gravitacijskih pojavov: Črni školj (a) v Trnovskem pokrovu, Suhi vrh (b) v Hrušiškem pokrovu ter Petelinje mlake (c) in Ilirska Bistrica (d) v Snežniškem pokrovu (sl. 1). Na območju Črnega ško- 
the gravitational phenomena: Črni školj (a) in the Trnovo Nappe Thrust Front, Suhi vrh (b) in the Hrušica Nappe Thrust Front, Petelinje mlake (c), and Ilirska Bistrica (d) in the Snežnik Nappe Thrust Front (Fig. 1). The Trnovo Nappe thrust plane lies at approximately $650 \mathrm{~m}$ a.s.l. in the Mala Gora fossil rotational landslide in the Črni školj area (Fig. 2). The thrust plane rises along the Mala Gora rotational landslide rupture surface at the Mt. Mali Modrasovec slope some $100 \mathrm{~m}$ to a height of $750 \mathrm{~m}$ a.s.l., and to $770 \mathrm{~m}$ a.s.l. along the road below Črni školj. Generally speaking, the thrust plane simply rises gently upward. A large area with slided blocks referred to as the Črni školj landslide area is described in detail by Kocjančič et al. (2019). The landslide area was formed as the result of the uplifted carbonate block with flysch in its base, and the denudational lowering of the Vipava valley. The Mala Gora fossil rotational slide is younger and dissects (cuts) the Črni školj landslide area.

The thrust plane on the SE slope of Mt. Nanos (Fig. 3) rises from $750 \mathrm{~m}$ a.s.l. south of Pleša (1262 m a.s.1.), up to $1000 \mathrm{~m}$ a.s.l. below Suhi vrh (1313 m a.s.l.) and descends down to $770 \mathrm{~m}$ a.s.l. beneath Mt. Tisovec (911 $\mathrm{m}$ a.s.1.). The specific structure of the Suhi vrh area - the result of extremely uplifted thrusted carbonate block with flysch in its base - is a consequence of gravitational processes. However, the structure differs from classical slides beneath Mt. Pleša and the V rtu peak (1108 $\mathrm{m}$ a.s.1.), due to the erosion and denudation of this part of the Postojna basin. Namely, the thrust plane of the Trnovo and Hrušica Nappes are uplifted and convexly bent behind the thrust front, but far less so in the Hrušica than in the Trnovo Nappe.

Unfortunately, we do not have knowledge of the structural base that would help us better understand the landslide at Petelinje mlake (Fig. 4), as the area hasn't been mapped in detail. Its position, two kilometres behind the thrust front is remarkable, reflecting significant post-thrusting modifications and a specific type of formation. The Juršče fault is surprising, as it seems to have been formed after the triggering of the Ilirska Bistrica landslide. The Ilirska Bistrica landslide (Fig. 5) was formed by the slipping of the carbonate block belonging to the Snežnik Nappe along the flysch basement. There is no evidence of the convex thrust plane bending, but the erosional deepening of the Reka river is certain. A unique rotational landslide formed owing to the close proximity of the Raša right lateral strike-slip fault, and the opening up of the pull-apart basin within the fault zone. The pull-apart basin was situated just beneath the lja (sl. 2) se narivna ploskev Trnovskega pokrova $\mathrm{v}$ fosilnem rotacijskem plazu Mala Gora nahaja približno na koti $650 \mathrm{~m}$. V pobočju Malega Modrasovca se ob drsni ploskvi plazu Mala Gora dvigne za okoli $100 \mathrm{~m}$ na $750 \mathrm{~m}$, ob cesti pod Črnim školjem pa sega do višine okoli $770 \mathrm{~m}$. V splošnem lahko rečemo, da se rahlo dviga. Pod pobočjem med Črnim školjem, Malim Modrasovcem in Malo Goro je obsežno območje zdrselih blokov, ki ga imenujemo plazišče Črni školj. Podrobno so ga opisali Kocjančič in sodelavci (2019). Nastalo je zaradi dviga narinjenega karbonatnega bloka s flišem v podlagi in denudacijskega nižanja nivoja Vipavske doline. Fosilni rotacijski plaz Mala Gora je mlajšega datuma in seka plazišče Črni školj.

V jugovzhodnem pobočju Nanosa (sl. 3) se narivna ploskev od kote 750 južno od Pleše (1262 m) dvigne do $1000 \mathrm{~m}$ pod Suhim vrhom $(1313 \mathrm{~m})$, nakar se spusti na $770 \mathrm{~m}$ pod Tisovcem $(911 \mathrm{~m})$. Območje Suhega vrha ima zaradi ekstremnega dviga narinjenega karbonatnega bloka s flišem $\mathrm{v}$ podlagi specifično zgradbo, ki je posledica gravitacije, vendar se razlikuje od klasičnih pobočnih zdrsov pod stenami med Plešo in vrhom V rtu (1108 m), ki jih je povzročila erozija in denudacija tega dela Postojnske kotline. Pri Trnovskem in Hrušiškem pokrovu se je narivna ploskev za čelom pokrova dvignila in konveksno usločila, vendar pri Hrušiškem bistveno bolj kot pri Trnovskem.

Pri Petelinjih mlakah (sl. 4) strukturna osnova za nastanek plazu ni jasna, ker območje ni natančneje kartirano. Izjemna je njegova lega dva kilometra za čelom Snežniškega pokrova, ki kaže na velike postnarivne spremembe in na specifične pogoje nastanka. Preseneča Jurški prelom, ki je moral nastati po sprožitvi plazu. Ilirskobistriški fosilni plaz (sl. 5) je nastal tako, da je karbonatni blok Snežniškega pokrova zdrsnil po flišni podlagi. Tu nimamo dokazov, da bi se narivna ploskev konveksno izbočila, zagotovo pa se je erozijsko poglobila dolina reke Reke. Do nastanka edinstvenega rotacijskega plazu je prišlo zaradi bližine desnozmičnega Raškega preloma in razprtja bazena tipa pull-apart znotraj njegove širše prelomne cone. Bazen je ležal tik pod pobočjem narivnega čela, tako da je to ob razprtju izgubilo oporo in zdrsnilo navzdol (Placer \& Jamšek, 2011). Pojav je moral biti hipen, kar ga povezuje s seizmičnim dogodkom. Bistriški pul-apartski bazen je pokrivWal osrednji del Bistriške kotline pod plazom. 
thrust front slope, lost stability, and collapsed at the opening of the basin (Placer \& Jamšek, 2011). The collapse had to be instantaneous which brings it in relation with a seismic event. The Ilirska Bistrica pull-apart basin covered the central part of the Ilirska Bistrica basin beneath the landslide.

\section{Gravitational phenomena on the SE slope of Mt. Nanos}

The SE slope of Mt. Nanos reveals some insight into the structure of the fore and rear parts of the Hrušica Nappe Thrust Front, as well as the morphology of its thrust plane, which was deformed in post-thrust processes. The gravitational phenomena at Suhi vrh reflects these deformation (processes).

\section{Structure of Mt. Nanos and Mt. Hrušica}

Mt. Nanos is part of a vast and extensive Hrušica Nappe Thrust Front composed of Jurassic and Cretaceous carbonate rocks and unconformably deposited Eocene flysch (Fig. 6). At the NW part a large NW-plunging anticline in the NW turns into a recumbent one thrusted upon the Snežnik Nappe Eocene flysch (in the central and eastern parts of the Postojna basin), and the External Dinaric Imbricated Belt, also referred to as parautochton (Rebrnice and $\mathrm{W}$ part of the Postojna basin). Also, part of the External Dinaric Imbricated Belt is the Jurassic carbonate Šmihel klippe (Čar \& Juren, 1980). Jurassic and Cretaceous carbonate rocks, as part of the Trnovo Nappe, are thrust upon the Eocene flysch belonging to the Hrušica Nappe (Srednja gora, 1275 m a.s.l., Streliški vrh, 1266 m a.s.l.) (Fig. 6.).

The Snežnik Nappe thrust plane crosses the western part of the Postojna basin. The thrust plane is identifiable in the Hruševje area, where the carbonate rocks of the Snežnik Nappe are thrust upon the External Dinaric Imbricated Belt, but NW of Hrušica the flysches of both nappes meet, hence the trace is not identified there. Detailed sedimentological and paleontological mapping would be required to determine the Snežnik Nappe thrust plane trace there. A thrust plane trace is only provisionally shown in Figure 6 .

The structure of the lower part of the Hrušica Nappe between Strane, Predjama, and Studeno differs from the upper part; however, there is not enough data on the Buser's (1967) geologic map to construct the correct structural interpretation. The unconformity between the Upper Cretaceous limestone and marl (scaglia), and the Eocene flysch between Strane and Studeno represents the main problem in the map. Following the bound-

\section{Gravitacijski pojavi na jugovzhodnem pobočju Nanosa}

Jugovzhodno pobočje Nanosa ponuja vpogled v notranjo zgradbo čelnega in začelnega dela krovne enote Hrušiškega pokrova in morfologijo njegove narivne ploskve. Ta je bila deformirana $\mathrm{v}$ postnarivnih procesih. Gravitacijski pojav Suhi vrh je odraz teh deformacij.

\section{Zgradba Nanosa in Hrušice}

Nanos leži v čelu obsežnega Hrušiškega pokrova, zgrajen je iz jurskih in krednih karbonatnih kamnin ter diskordantno odloženega eocenskega fliša (sl. 6). Plasti krovne enote tvorijo na severozahodu veliko proti SZ tonečo antiklinalo, na jugovzhodu pa veliko poleglo antiklinalo, ki sta narinjeni na eocenski fliš Snežniškega pokrova (osrednji in vzhodni del Postojnske kotline) in Zunanjedinarskega naluskanega pasu ali paravtohtona (Rebrnice, zahodni del Postojnske kotline). Del Hrušiškega pokrova je tudi Šmihelska tektonska krpa iz jurskih plasti (Čar \& Juren, 1980). Severno od Nanoške antiklinale so na eocenski fliš Hrušiškega pokrova narinjeni jurski in kredni karbonati Trnovskega pokrova (Srednja gora $1275 \mathrm{~m}$, Streliški vrh 1266 m) (sl. 6).

Preko zahodnega dela Postojnske kotline poteka narivnica Snežniškega pokrova, ki je določljiva na območju Hruševja, kjer so karbonati Snežniškega pokrova narinjeni na fliš Zunanjedinarskega naluskanega pasu. Od Hruševja proti severozahodu potek narivnice ni določen, ker se tu stikata fliša obeh krovnih enot. Za njeno določitev bi bilo potrebno izvesti detajlno sedimentološko in paleontološko profiliranje. $\mathrm{Na}$ sliki 6 je potek narivnice le nakazan.

Spodnji ustroj Hrušiškega pokrova med Stranami, Predjamo in naprej do Studenega je zgrajen drugače kot zgornji del, vendar na OGK, list Postojna (Buser et al., 1967) ne najdemo dovolj podatkov za korektno strukturno rešitev tega vprašanja. Glavni problem na karti predstavlja diskordantna meja med zgornjekrednim apnencem in laporjem (scaglia) ter eocenskim flišem med Stranami in Studenim, ki bi glede na vpad plasti in potek na površju (pravilo V) morala biti inverzna. Ker pa razvoj plasti nad diskordanco kaže na poševni rez, je Placer (1981) to mejo interpretiral kot krovno narivno ploskev, zgornjekredne in spodnjekredne plasti v krovni grudi pa razvrstil v tri vmesne krovne luske. Taka razdelitev bi po analogiji ustrezala spodnjemu ustroju Trnovskega pokrova na območju Idrije (Mlakar, 1969). Čar \& Šebela 


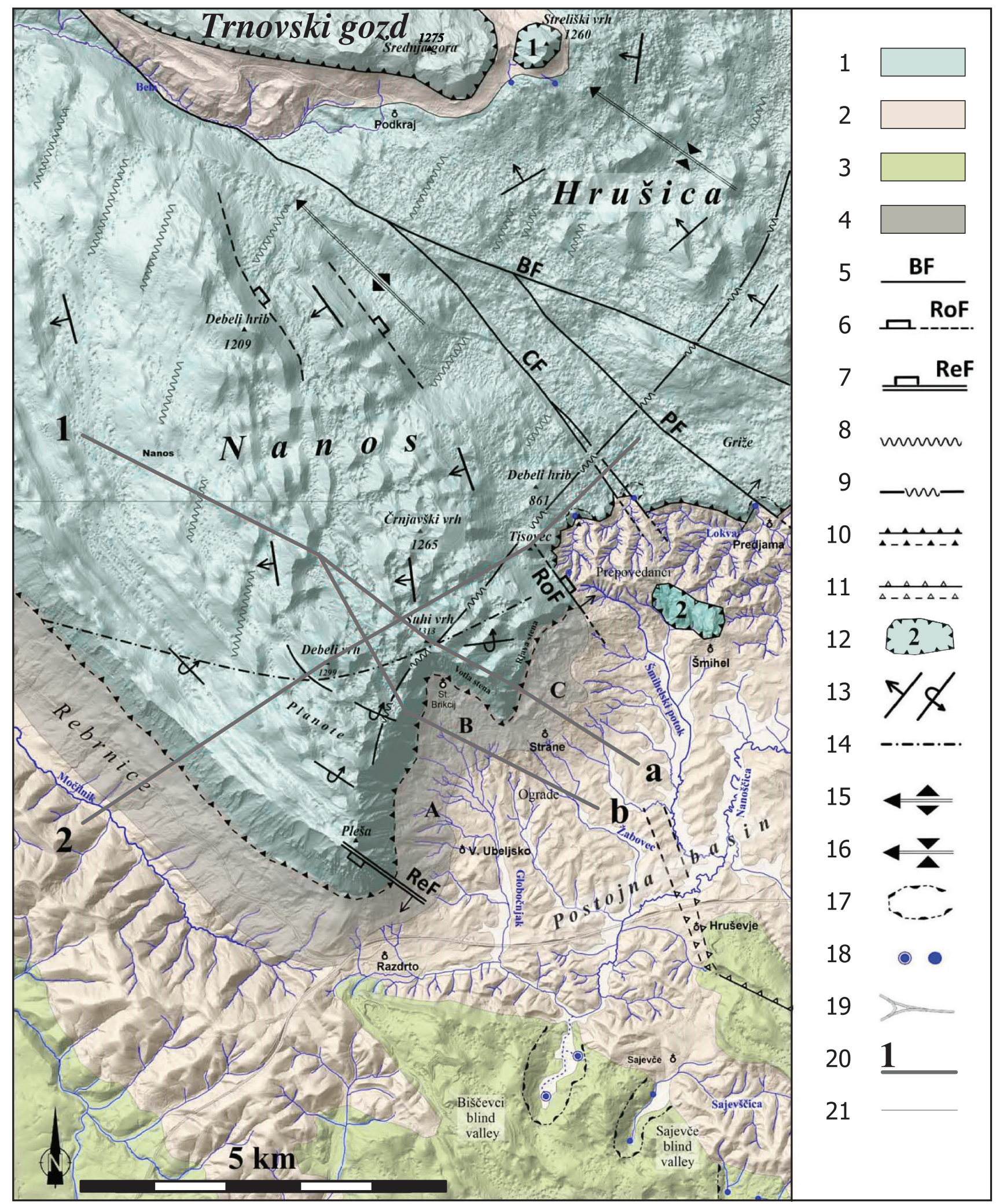

Fig. 6. Geological - geomorphological sketch of Mt. Nanos a part of Mt. Hrušica

Sl. 6. Geološko-geomorfološka skica Nanosa in dela Hrušice.

1 Mesozoic carbonates / mezozojski karbonati

2 Eocene flysch / eocenski fliš

3 Mezozoic and Paleogene carbonates / mezozojski in paleogenski karbonati

4 Landslide areas / plazišča: Rebrnice, A - »Ubeljska stena«, B - Votla stena, C - Rjava stena

5 Strike-slip fault / zmični prelom: BF - Belsko fault / Belski prelom, CF - Črnjavska dolina fault / Črnjavski prelom, PF - Predjama fault / Predjamski prelom

6 Normal fault / normalni prelom: RoF - Roček fault and inferred faults of the similar mechanism / RoF - Ročkov prelom in domnevni prelomi enakega mehanizma

7 Normal fault with hereditary gravitational slide / normalni prelom z nasledstvenim gravitacijskim zdrsom: ReF - Reševnik fault / Reševniški prelom 
8 Regional sub-vertical fractures (strike angle $20^{\circ}-40^{\circ}$ ) / regionalne subvertikalne razpoke smeri $20^{\circ}$ do $40^{\circ}$

9 Deformational curve of the regional fractures with $20^{\circ}$ to $40^{\circ}$ strike angle due to right lateral offset along the Belsko fault / deformacijska krivulja regionalnih razpok $20^{\circ}$ do $40^{\circ}$ zaradi desnega premika ob Belskem prelomu

10 Hrušica Nappe boundary / meja Hrušiškega pokrova

11 Snežnik Nappe boundary / meja Snežniškega pokrova

12 Tectonic klippe / tektonska krpa: 1 - Streliški vrh t. k. / Streliška t. k., 2 - Šmihel t. k. / Šmihelska t. k.

13 Bedding: normal, inverse / plasti: normalne, inverzne

14 Axial plane of the recumbent frontal anticline / osna ravnina polegle krovne antiklinale

15 Mt. Nanos anticline axis / os Nanoške antiklinale

16 Hrušica syncline axis / os Hrušiške sinklinale

17 Blind valley rim / rob slepe doline

18 Spring, sinkhole / izvir, ponor

19 Motorway / avtocesta

20 Position of geological cross-sections 1a, 1b (Fig. 11) and 2 (Fig. 16) / lega profilov 1a, 1b (sl. 11) in 2 (sl. 16)

21 Geological boundary / geološka meja

ary course on the surface (according to the V-rule) it should be in inverse position. However, Placer, (1981) interpreted the boundary as a low-angle thrust fault (a sole thrust), since the structure above the unconformity indicates an oblique cut. The Upper and Lower Cretaceous beds in the hanging wall are interpreted as three intermediate duplexes. Such an interpretation is analogous to the structure of the lower part of the Trnovo Nappe in the Idrija area (Mlakar, 1969). Mapping the Predjama area (Čar \& Šebela, 2001) confirmed a tectonic boundary between the Eocene flysch and the Cretaceous beds and, consequentially, Placer's (1981) interpretation. The upper level of the Hrušica Nappe structure between Studeno and Strane is simple: Upper Cretaceous and Jurassic carbonates are thrust upon the Upper and Lower Cretaceous carbonates of the lower level. In general, the described structure confirms the interpretation with intermediate duplexes, only they are fewer in number, with only one or two east of Tisovec and probably none between Tisovec and Strane. The duplexes are here included in the Hrušica Nappe, as these issues are not of particular importance for our purposes herein.

After the thrusting, a large recumbent Nanos anticline (Limanowski, 1910; Buser, 1967; Placer, 1981) in the thrust front of the Hrušica Nappe was regionally folded into the Nanos anticline and Hrušica syncline.

The principal structural elements of the Hrušica Nappe are presented in Figure 6. The recumbent Nanos anticline in the Hrušica Nappe Thrust Front is defined by the position of the northward dipping recumbent fold's axial plane, dividing the normal from the inverse strata. The Nanos anticline and Hrušica syncline axes plunge in the NW direction.

The Hrušica Syncline is cut by the Predjama fault, a dislocation named by Buser (1976), who defined the fault according to stratigraphic
(2001) sta pri Predjami s kartiranjem potrdila tektonsko mejo med zgornjekrednim apnencem in flišem kar je v splošnem potrjevalo Placerjevo domnevo. Zgradba zgornje etaže Hrušiškega pokrova je drugačna toda enostavna, na obravnavanem odseku jo sestavljajo zgornjekredni in jurski karbonati, ki so narinjeni na spodnje in zgornjekredne karbonate spodnjega ustroja. Vse to v splošnem potrjuje interpretacijo s krovnimi vmesnimi luskami, le da je njihovo število manjše; med Stranami in Tisovcem verjetno ni nobene, vzhodno od Tisovca pa ena ali dve. V tem članku to vprašanje ni toliko pomembno, zato so vmesne luske vključene v Hrušiški pokrov.

Velika polegla nanoška čelna antiklinala (Limanowski, 1910; Buser, 1967; Placer, 1981) je bila z ostalim delom Hrušiškega pokrova v postnarivnem obdobju regionalno nagubana, tedaj sta nastali Nanoška antiklinala in Hrušiška sinklinala.

Na sliki 6 so podani glavni strukturni elementi Hrušiškega pokrova. Polegla krovna antiklinala je določena $\mathrm{z}$ lego osne ravnine, ki ločuje inverzne in normalne plasti in vpada generalno proti severu. Osi Nanoške antiklinale in Hrušiške sinklinale toneta proti severozahodu.

Hrušiško sinklinalo seka dislokacija, ki jo je Buser poimenoval Predjamski prelom; po stratigrafskih kriterijih ga je povlekel mimo Predjame in ga proti severozahodu povezal s prelomom po dolini Bele, nato s prelomom mimo Predmeje in naprej s prelomom Avče-Dol. Jugovzhodno od Predjame ga je podaljšal v Snežniško hribovje (Buser, 1976), na OGK (Buser et al., 1967) pa tega preloma JV od Predjame ni vrisal. Na lidarju je razvidno, da se glavna prelomna ploskev, ki poteka po dolini Bele, nadaljuje v smeri ESE proti Belskemu, kjer močno premakne narivnico Hrušiškega pokrova. Prelom, ki poteka mimo Predja- 
criteria. Buser drew the fault trace along Predjama and connected it in the NW direction with a fault along the Bela valley, further due NW with a fault passing Predmeja, and still further with the Avče - Dol fault. Southeast of Predjama, Buser (1976) extended the fault into the Snežnik hills, but this fault segment is not yet drawn on the Buser's geological map (Buser et. al., 1967). It is clear from the lidar image that the main fault plane from the Bela valley continues due ESE toward Belsko, where it considerably offsets the Hrušica Nappe thrust plane. The fault passing Predjama is only a secondary fault (branch) detached from the main fault plane. We suggest therefore, naming the Bela fault that fault that runs along the Bela valley and passes Belsko, while the splay (secondary fault) passing Predjama (30/75) should retain the name Predjama fault. The latter dies out due SE within a relatively short distance, much like the other Bela fault's secondary branches (splays). There are many secondary faults leaning on the Bela fault, and all host geomorphologically responsive sinkholes: the Črnjavska dolina fault hosts a Prepovedanci sinkhole, the Predjama fault, and the Bukovje fault (Čar \& Šebela, 2001). Apart from the aforementioned right lateral strike-slip secondary faults, other N-NW trending sub-vertical faults with subsided NW blocks are also important. They too lean on the Bela fault, but only the Roček fault (70/80) among them has been named (after the Roček hot spring).

The multiphase evolution of the Bela fault and both sets of described secondary faults leaning on it (the ones with a strike-slip, as well as those of normal character, is reflected in various geomorphologic effects. Significant vertical offsets are obvious along the normal faults (e.g., Roček fault), while no vertical offsets are observed along the strike-slip faults. However, discussing the genesis of these fault systems is not the purpose of this article.

We propose the name Predmeja fault for the northern part of the Predjama fault (Buser, 1976), as the fault segment between Predmeja and Col reflects the highest geomorphic response.

A NNE-SSW (roughly $20^{\circ}$ ) trending system of subvertical fractures stands out over the entire Hrušica Nappe area. Due to the dextral strikeslip motion of the Bela fault these fractures are sigmoidally bent and trend in the SW-NE (roughly $40^{\circ}$ ) direction in their most deformed part.

The Reševnik fault (210/60) is exposed just behind the Hrušica Nappe Thrust Front above Razdrto. Its principal and parallel secondary fault planes later adopted the role of gravitationally generated slip planes. The Reševnik fault is me je le sekundarni odcep omenjene glavne prelomne ploskve. Zato predlagamo, da se prelom, ki poteka po dolini Bele in gre na Belsko imenuje Belski prelom, Predjamski prelom pa naj se imenuje le sekundarni krak, ki poteka mimo Predjame (30/75) in proti jugovzhodu, tako kot drugi sekundarni prelomi Belskega preloma, kmalu zamre. Sekundarnih krakov, ki se naslanjajo na Belski prelom je več, ob vseh so nastali geomorfološko odzivni ponori. To so Črnjavski prelom (Črnjavska dolina), ob katerem je nastal ponor na Prepovedancih, Predjamski prelom in Bukovski prelom (Čar \& Šebela, 2001) mimo Bukovja. Poleg omenjenih sekundarnih desnozmičnih prelomov so pomembni še subvertikalni prelomi v smeri NNW-SSE, ob katerih je severovzhodno krilo ugreznjeno. Tudi ti se naslanjajo na Belski prelom; od teh je poimenovan le Ročkov prelom (70/80).

Belski prelom z obema snopoma sekundarnih prelomov, zmičnih in subvertikalnih z vertikalno komponento premika, kaže na večfazni razvoj z različnimi geomorfološkimi učinki. Ob prelomih zmičnega snopa ni v reliefu vertikalnih skokov, ob prelomih tipa Ročkov prelom, pa je opazna izdatna stopnja v reliefu. Geneza teh sistemov ni predmet tega članka.

Za segment Buserjevega Predjamskega preloma med Predmejo in Colom (Buser, 1976) predlagamo, da se preimenuje v Predmejski prelom, ker je ta odsek na celotni trasi geomorfološko najbolj odziven.

Na celotnem območju Hrušiške krovne enote izstopa sistem regionalnih subvertikalnih razpok v smeri SSW-NNE (okoli $20^{\circ}$ ). Te so zaradi desnega zmika ob Belskem prelomu v smeri WNW-ESE regionalno sigmoidalno usločene, tako da imajo $\mathrm{v}$ najbolj zasukanem delu smer SW-NE (okoli $40^{\circ}$ ).

V boku Hrušiškega pokrova je takoj za njegovim čelom nad Razdrtim viden Reševniški prelom $(210 / 60)$, katerega glavna in vzporedne prelomne ploskve so pozneje prevzele vlogo gravitacijskih drsnih ploskev. Reševniški prelom je viden le v jugovzhodnem pobočju Nanosa, na površju proti severozahodu pa še ni bil sleden.

Pobočni zdrsi so prisotni povsod, kjer so karbonati na flišu ekstremno dvignjeni nad krajino. Na slikah 6 in 8 so razdeljeni na tiste pod čelom nariva (Rebrnice) in na tiste pod jugovzhodnim pobočjem Nanosa pod »Ubeljsko«, Votlo in Rjavo steno. Ime »Ubeljska stena« ne obstaja v geografski ali ljudski terminologiji, uvedli smo ga iz praktičnih razlogov in zajema strmo pobočje med Razdrtim in Votlo steno. 


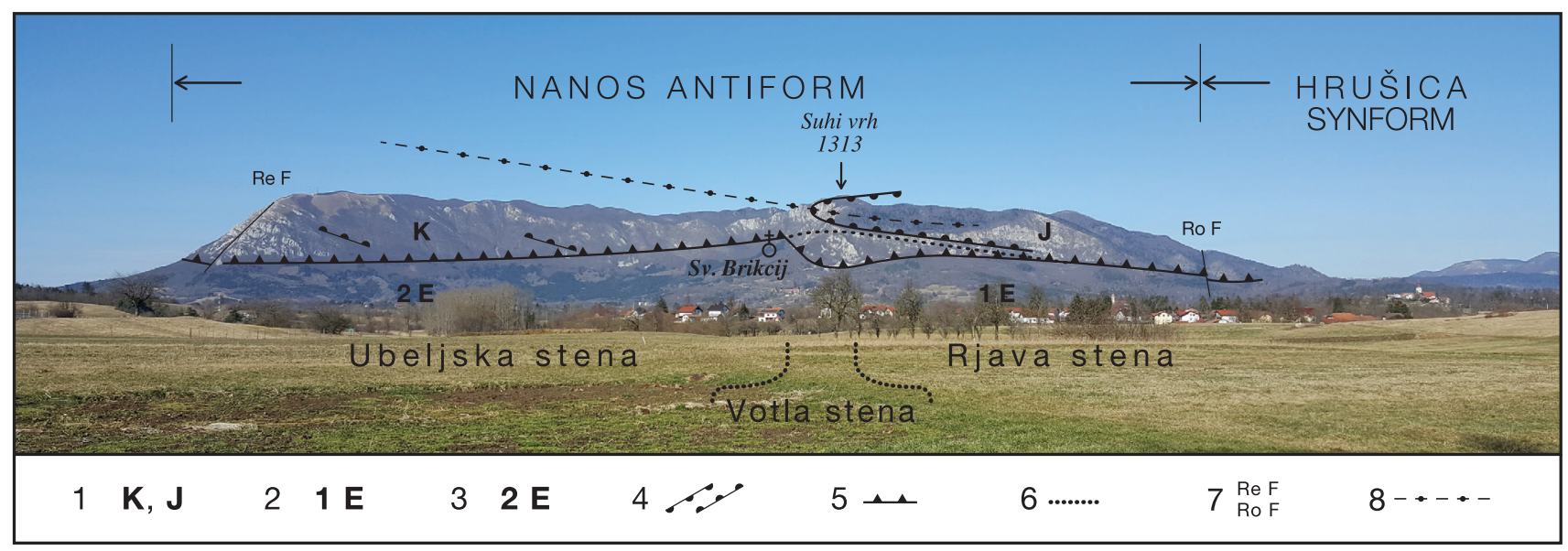

Fig. 7. Panoramic photography of the SE slope of Mt. Nanos and transverse geological cross-section of the Hrušica Nappe front part.

S1. 7. Panorama jugovzhodnega pobočja Nanosa in prečni geološki profil čelnega dela Hrušiškega pokrova.

1 Hrušica Nappe / Hrušiški pokrov: J - Jurassic carbonates / jurski karbonati, K - Cretaceous carbonates / kredni karbonati $21 \mathrm{E}$ - Eocene flysch of the Snežnik Nappe / eocenski fliš Snežniškega pokrova

$32 \mathrm{E}$ - Eocene flysch of the External Dinaric Imbricated Belt / eocenski fliš Zunanjedinarskega naluskanega pasu

4 Bedding: normal, inverse / plasti: normalne, inverzne

5 Hrušica Nappe boundary / meja Hrušiškega pokrova

6 Hrušica Nappe boundary projection in the Ubeljska stena cross-section / projekcija meje Hrušiškega pokrova v ravnini profila Ubeljske stene

7 Normal fault / normalni prelom: ReF - Reševnik fault / Reševniški prelom, RoF - Roček fault / Ročkov prelom

8 Axial plane of the recumbent frontal anticline / osna ravnina polegle krovne antiklinale

only observable on the SE slope of Mt. Nanos and has not yet been mapped due NW.

Landslides are present wherever carbonates lying on flysch are uplifted high above the surrounding landscape. Landslides are divided into those beneath the thrust front (Rebrnice) and those on the SE slope of Mt. Nanos (beneath the Ubeljska stena, Votla stena and Rjava stena) (Figs. 6 and 8). An "Ubeljska stena" toponym does not exist in geographical or other terminology. We introduced the term for practical purposes in order to refer to the steep slope between Razdrto and Votla stena.

The structure of the Hrušica Nappe front exposed on the SE slope of Mt. Nanos between Razdrto and Roček spring (Fig. 8) is presented in the panoramic photo (Fig. 7). Geologic cross-sections are constructed across and parallel to the view in Figure 7. The most important part of the geological structure there is a recumbent anticline reconstructed from its visible core in the Votla stena, just beneath Suhi vrh. The inverse strata are present from the Ubeljska stena, across Votla and Rjava stena. Its axial plane rises towards the thrust front and should lean on the thrust plane in the opposite direction. However, this point (where the recumbent fold's axial plane meets the thrust plane) is not determinable due to scarce structural data on the geological map (Buser et al., 1967). An inverse limb more than $4 \mathrm{~km}$ long is surprising.
Zgradba čelnega in začelnega dela krove enote Hrušiškega pokrova je vidna v jugovzhodnem pobočju Nanosa med Razdrtim in izvirom Roček (sl. 8). Predstavljena je na panoramskem posnetku na katerem je skiciran strukturni profil (sl. 7). Tu je najpomembnejši element strukture rekonstruirana polegla krovna antiklinala, ki je izvedena iz njenega vidnega jedra $\mathrm{v}$ Votli steni tik pod Suhim vrhom. Inverzne plasti se raztezajo preko Ubeljske, Votle in Rjave stene. Osna ravnina polegle antiklinale se proti čelu pokrova dviguje, v nasprotno smer pa bi se morala naslanjati na narivno ploskev, vendar te točke ni mogoče določiti zaradi skopih strukturnih podatkov na OGK, list Postojna (Buser et al., 1967). $\mathrm{V}$ profilu preseneča izdatna dolžina inverznega krila, ki presega 4 kilometre.

Narivna ploskev v profilu na sliki 7 je določena po morfoloških znakih v pobočju, kjer poteka pod pregibom med strmo karbonatno steno $\mathrm{v}$ krovnini in flišnim pobočjem $\mathrm{v}$ talnini, ki je položnejše in prekrito s pobočnim gruščem in plazovi. Razen nad Sv. Brikcijem ni fliša videti nikjer. V steni nad Razdrtim je videti Reševniški prelom, kjer se narivna ploskev od $750 \mathrm{~m}$ dvigne za nekaj deset metrov na $800 \mathrm{~m}$, proti Sv. Brikciju pa se vedno bolj strmo dviga do $1000 \mathrm{~m}$. Pod Votlo steno se spusti do višine $850 \mathrm{~m}$ nad Stranami, od koder se polagoma spušča do Ročkovega preloma, kjer doseže višino okoli $770 \mathrm{~m}$. Na drugi strani pre- 


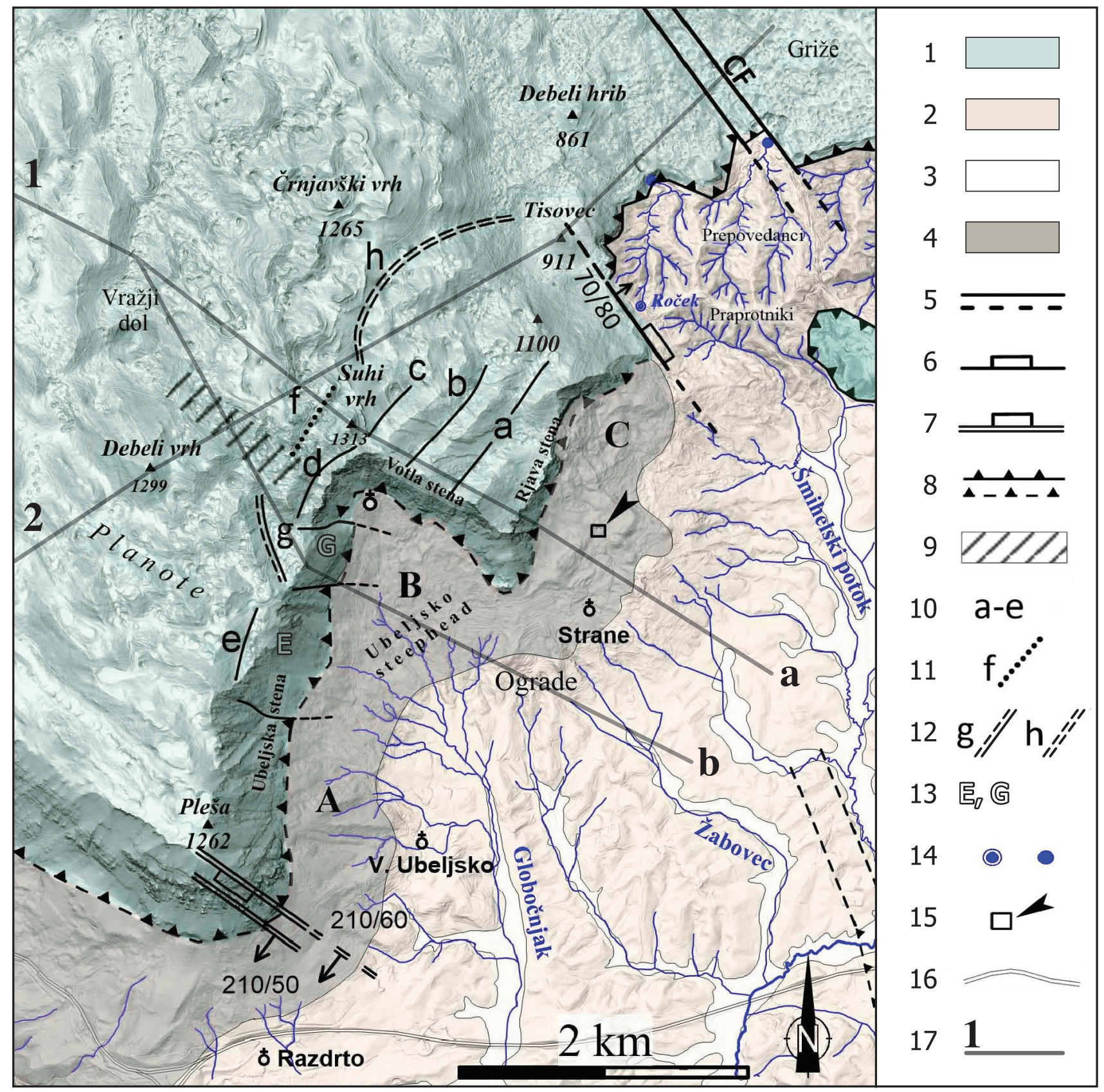

Fig. 8. Geological - geomorphological sketch of the SE part of Mt. Nanos.

Sl. 8. Geološko - geomorfološka skica jugovzhodnega dela Nanosa.

1 Mesozoic carbonates / mezozojski karbonati

2 Eocene flysch / eocenski fliš

3 Alluvium / aluvij

4 Landslide areas / plazišča: Rebrnice, A - »Ubeljska stena«, B - Votla stena, C - Rjava stena

5 Strike-slip fault / zmični prelom: CF - Črnjavska dolina fault / Črnjavski prelom

6 Normal fault / normalni prelom: RoF - Roček fault 70/80 / Ročkov prelom 70/80

7 Normal fault with hereditary gravitational slide / normalni prelom z nasledstvenim gravitacijskim zdrsom: ReF - Reševnik fault 210/60 / Reševniški prelom 210/60

8 Nappe boundary / meja pokrova

9 Tectonized zone within the recumbent frontal anticline core / tektonizirana cona v jedru prevrnjene krovne antiklinale

10 Shear razdol / strižni razdol: a, b, c, d, e

11 Divergent razdol / razmični razdol: f

12 Marginal trench / robni jarek: g - probable / verjetni, $\mathrm{h}$ - inferred / domnevni

13 Gravitational block / gravitacijski blok: E, G

14 Spring, sinkhole / izvir, ponor

15 Gravel pit, reversely rotated bedding (Fig. 10) / občasni kop gramoza, povratno rotirane plasti (sl. 10)

16 Motorway / avtocesta

17 Position of geological cross-sections 1a, 1b (Fig. 11) and 2 (Fig. 16) / lega profilov 1a, 1b (sl. 11) in 2 (sl. 16) 
The thrust plane in the cross section in Figure 7 is defined by the morphologic features on the slope that appear a few metres below the inflection point, between a steep carbonate slope belonging to the hanging wall and a more gradual flysch footwall slope covered by the slope scree and landslides. Flysch is exposed only above Sv. Brikcij (St. Brictius). The Hrušica Nappe thrust plane is located at $750 \mathrm{~m}$ a.s.l. in the thrust front above Razdrto. On the other side of the Reševnik fault it rises to $800 \mathrm{~m}$ a.s.l. and rises ever more steeply up to $1000 \mathrm{~m}$ a.s.l. at Sv. Brikcij. Beneath the Votla stena the thrust plane drops down to $850 \mathrm{~m}$ a.s.l. above Strane and descends down to $770 \mathrm{~m}$ a.s.l. at the Roček Fault. Across the fault, it drops to $730 \mathrm{~m}$ a.s.l. and gradually descends down to the lowest point (on this section) at $500 \mathrm{~m}$ a.s.l. at Predjama. The cross-section geometry is distorted, as the Rjava stena and Ubeljska stena don't lie on the same plane, but lie closer to the observer for a distance roughly the length of the Votla stena (about $1500 \mathrm{~m}$ ) (Fig. 6). An inferred course of the Hrušica Nappe thrust plane in an extension of the Ubeljska stena is presented as a dotted line in Figure 7 and illustrates the apex of the convex bulge beneath Suhi vrh (1313 $\mathrm{m}$ a.s.l.), the highest geographic point in the area (of Mt. Nanos). However, the bulge and the highest peak do not coincide with the axis of the Nanos anticline. An explanation of this phenomena would go beyond the aim of this paper; however, let us summarize by stating that both the bulge and the Nanos anticline arose simultaneously, and that the reason for this peculiarity lies in the internal structure of the Hrušica Nappe. Here we are confronted by two different structural features formed in the same folding phase. The (convex) bulge in the flysch base has an anticlinal form, hence the Nanos flysch antiform. Not only is the flysch in the base cambered, but the entire nappe, so we can generally refer to this feature as the Nanos antiform.

The Nanos antiform, recumbent Nanos anticline and Hrušica syncline reflect the regional importance of the post-thrusting folding. A Hrušica synform can be deduced from the existence of the Nanos antiform, but unfortunately, we cannot directly prove it, as the Hrušica Nappe thrust plane isn't exposed in the NE block of the Idrija fault. We do, however, find a hint (in the form of circumstantial evidence) in the post-thrust Trnovo Nappe structure that the Hrušica thrust plane, at some depth, continues also to the NE. The Križna gora synform structure at the SE margin of Trnovo Nappe north of Srednja gora (1275 m a.s.l.) (Fig. 6) formed in the core of the Hrušica syncline and continues under the central part of the Trnovski gozd loma naglo preskoči na okoli $730 \mathrm{~m}$ in se potem polagoma spušča do Predjame, kjer leži nekaj pod $500 \mathrm{~m}$. Tu je najbolj spuščena na tem odseku meje Hrušiškega pokrova. Prerez narivne ploskve je popačen, ker Rjava stena ne leži v ravnini Ubeljske stene, temveč je za dolžino Votle stene, okoli $1500 \mathrm{~m}$, pomaknjena proti opazovalcu (sl. 6). Lega narivne ploskve v namišljenem podaljšanem prerezu Ubeljske stene je narisana pikčasto (sl. 7) in lepo nakazuje vrh konveksne izbokline. Ta se nahaja pod Suhim vrhom (1313 m), ki je najvišja točka Nanosa in se ne pokriva z osjo Nanoške antiklinale. Gre za strukturno posebnost katere razlaga presega okvir tega članka, za sedaj pa je dovolj če vemo, da sta obe izbočeni strukturi nastali istočasno in da tiči izvor anomalije $\mathrm{v}$ notranji zgradbi krovne enote. Pred seboj imamo dva različna strukturna objekta, ki pa sta nastala $\mathrm{v}$ isti fazi gubanja. Konveksna izboklina flišne podlage ima obliko antiforme in jo imenujemo nanoška flišna antiforma. Izbočen ni samo fliš v podlagi temveč tudi narivna enota, zato govorimo v splošnem o nanoški antiformi.

Regionalni pomen postnarivnega gubanja Hrušiškega pokrova se kaže v obstoju nanoške antiforme, Nanoške antiklinale in Hrušiške sinklinale. Iz obstoja nanoške antiforme sklepamo tudi na obstoj hrušiške sinforme, ki pa je ne moremo neposredno dokazati, ker na severovzhodni strani Idrijskega preloma narivnica Hrušiškega pokrova nikjer ne izdanja. Da se gubanje narivne ploskve nadaljuje v globini verjetno tudi proti severovzhodu, obstaja posredni namig v postnarivni zgradbi Trnovskega pokrova. V jedru Hrušiške sinklinale je razvita sinformna struktura Križne gore, ki leži na skrajnem JV robu Trnovskega pokrova, severno od Srednje gore (1275 m) (sl. 6). Sinforma se nadaljuje pod osrednji del Trnovskega gozda proti severozahodu (Placer \& Čar, 1974), proti severovzhodu se previje $\mathrm{v}$ antiformno strukturo Idrijskega tektonskega polokna, ta $\mathrm{v}$ sinformno strukturo Idrijsko-Žirovskega ozemlja in ta v antiformno strukturo Poljansko-Vrhniških nizov. Omenjene sinforme in antiforme imajo dinarsko smer. Lega sinformne strukture Križne gore v osi Hrušiške sinklinale pomeni, da sta nastali v isti fazi gubanja. 
due NW (Placer \& Car, 1974). To the NE it is cambered in an antiform structure of the Idrija tectonic half-window, and the Idrija tectonic half-window transits into the Žiri - Idrija synform which continues into the Poljane - Vrhnika hills antiform further to the northeast. These synforms share a NW (Dinaric) trend. The position of the Križna gora synform on the axis of the Hrušica syncline means that they both formed in the same folding phase.

\section{Structure of the southwestern part of Mt. Nanos}

Two unusual relief structures, the result of gravitational processes, surprise on the SE slope of Mt. Nanos, the steephead valley closed by the Ubeljska and Votla stena called the Ubeljsko steephead, and geological structure of the block behind the Votla and Rjava stena called the Suhi vrh gravitational structure. There, other classical slope features are present, as well in the Rebrnice slope and in the landslide areas (zones) named after the cliffs above them - the Ubeljska stena landslide area, the Votla stena landslide area, and the Rjava stena landslide area (Fig. 8).

\section{Zgradba jugovzhodnega dela Nanosa}

V jugozahodnem pobočju Nanosa presenečata dve neobičajni reliefni strukturi, ki sta posledici gravitacijskih procesov, prva je zatrep, ki ga zapirata Ubeljska in Votla stena, imenujemo ga ubeljski zatrep, druga je zgradba bloka v zaledju Votle in Rjave stene, imenujemo jo gravitacijska struktura Suhega vrha. Poleg tega so tu tudi klasični pobočni pojavi na plazišču Rebrnice in na plaziščih, ki jih poimenujemo po stenah nad njimi; plazišče Ubeljska stena, plazišče Votla stena in plazišče Rjava stena (sl. 8).

Plazišče Rebrnice se nahaja pod jugozahodnim pobočjem Nanosa, vendar prispeva poznavanje razmer na tem prostoru pomemben delež k razumevanju zgradbe celotnega območja. Za Rebrnice so značilni strukturni, rotacijski in zemeljski planarni plazovi ter podori, kot tudi (blatno) drobirsko plazenje in tečenje (Popit, 2016). Pomemben nasledstveni dejavnik nestabilnosti je tu Reševniški prelom (sl. 9), za katerega domnevamo, da je njegova prelomna ploskev v sedanjem stadiju denudacije čela

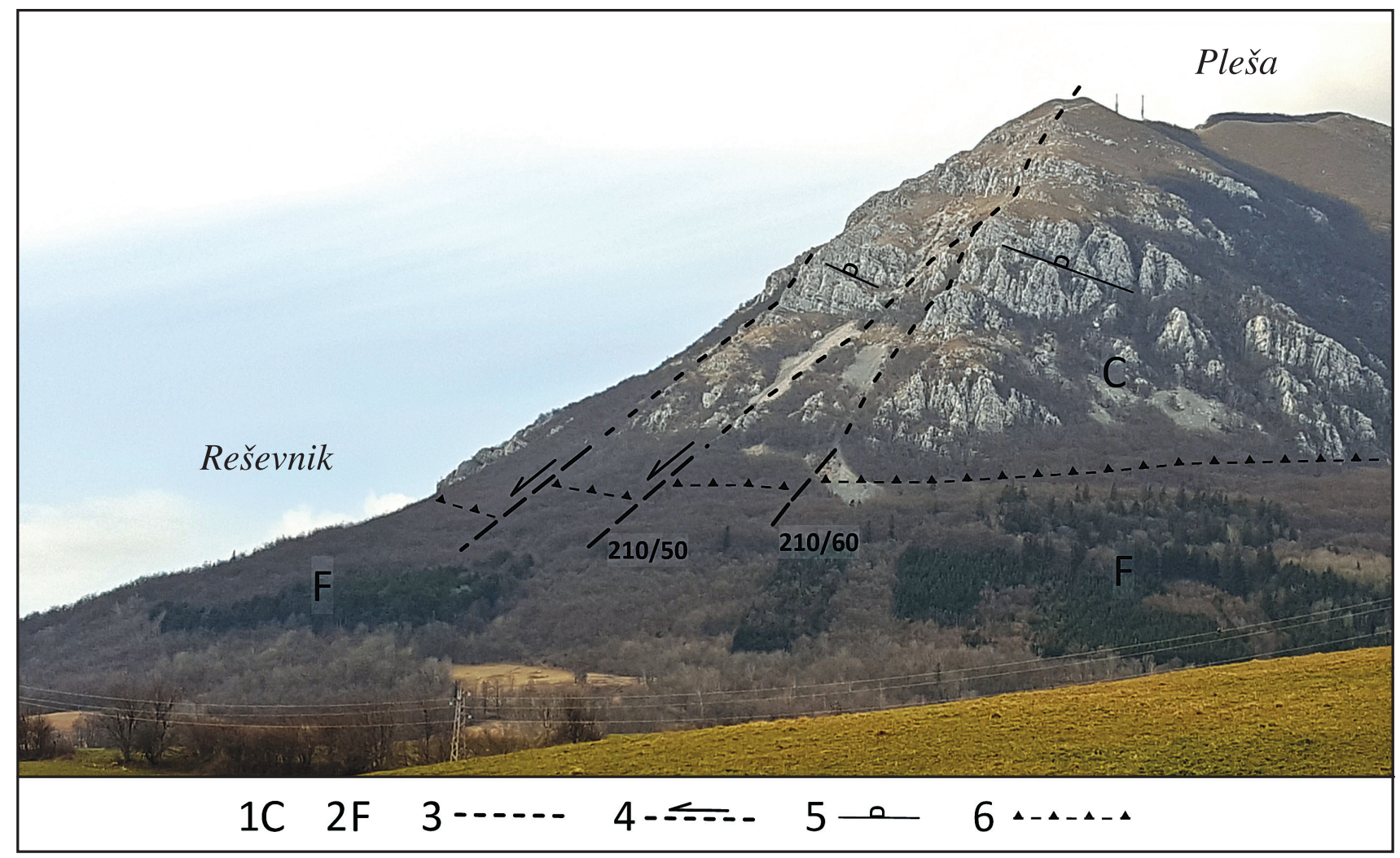

Fig. 9. Gravitational slide along the fault planes in the Reševnik fault zone. Hrušica Nappe front above Razdrto village.

Sl. 9. Gravitacijski zdrs po prelomnih ploskvah v coni Reševniškega preloma. Čelo Hrušiškega pokrova nad Razdrtim.

$1 \mathrm{C}$ - Hrušica Nappe carbonates / karbonati Hrušiškega pokrova

2 F - Flysch of the External Dinaric Imbricated Belt / fliš Zunanjedinarskega naluskanega pasu

3 Main fault plane 210/60 / glavna prelomna ploskev 210/60

4 Parallel fault plane 210/50 and other hereditary gravitational rupture planes / vzporedna prelomna ploskev 210/50 in ostale kot nasledstvene gravitacijske zdrsne ploskve

5 Inverse bedding / inverzne plasti

6 Hrušica Nappe boundary / meja Hrušiškega pokrova 


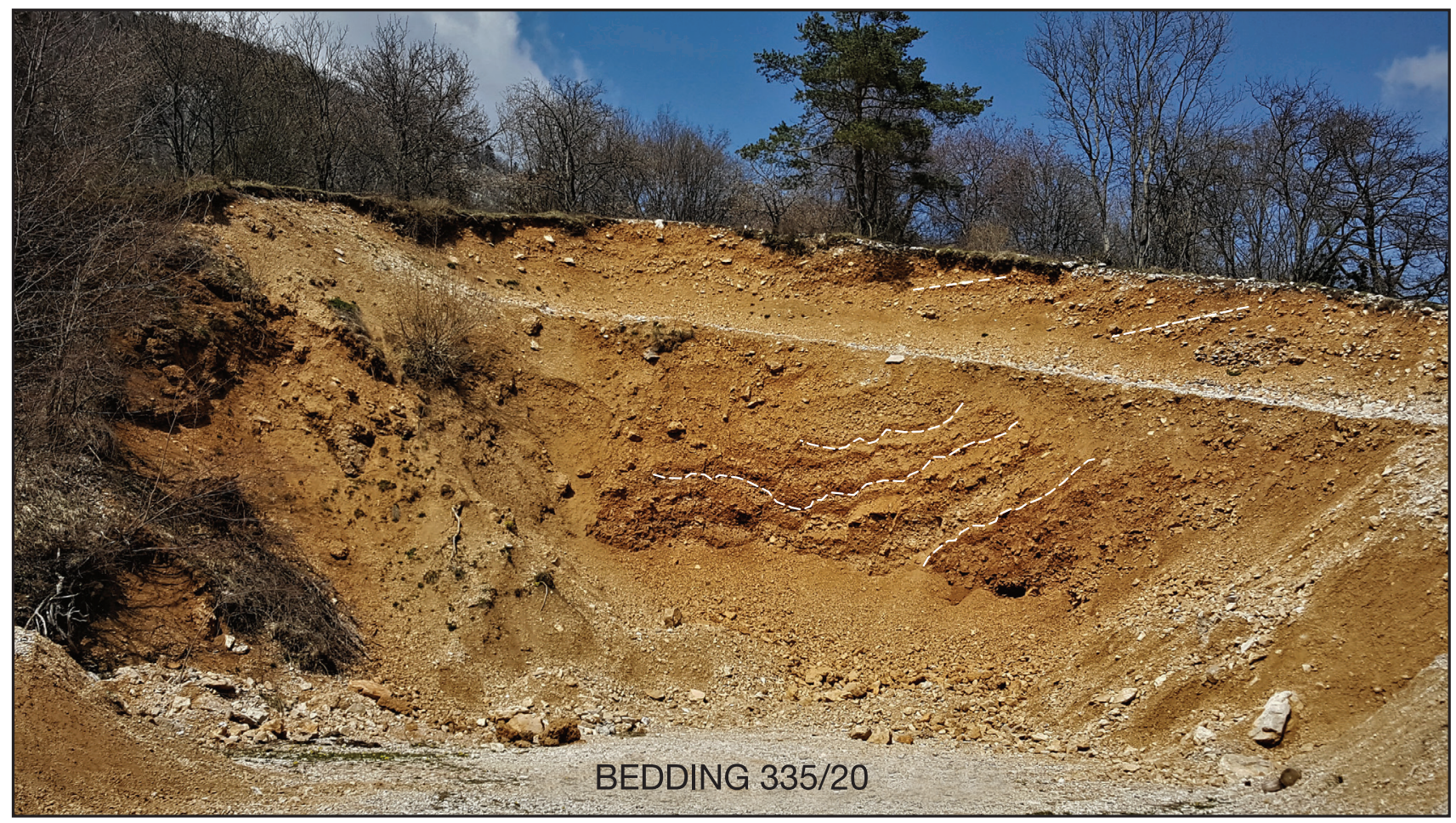

Fig. 10. Reversely rotated bedding of the rotational landslide in the gravel pit in the Rjava stena landslide area (Figs. 8 and 11, 1a). Sl. 10. Povratno zasukane plasti rotacijskega plazu v občasnem kopu gramoza na plazišču Rjava stena (sl. 8 in 11, 1a).

The Rebrnice landslide area is situated beneath the SW slope of Mt. Nanos, and its revealed structure contributes significantly to our understanding of the structure of the entire area. Structural and rotational landslides, translational earth slumps, rockfalls, as well as debris flows (Popit, 2016) are characteristic features of the Rebrnice. The Reševnik fault (Fig. 9) is an important hereditary factor of slope instability there, and it is inferred that its fault plane took over the role of the gravitational slip plane in the present denudation stage of the Hrušica Nappe Thrust Front. (The arguments for the interpretation are provided further into the text herein.) Slope scree and minor rockfalls prevail on the surface of the Ubeljska stena and Votla stena landslide areas. More important, however, is the Rjava stena landslide area, where large block slides and rockfalls prevail in the northern part, and rotational landslides in the southern part, respectively. A rotated dip (335/20) in the displaced material of a fossil rotational rubble slide above the village of Strane is presented in Figure 10. Popit (2017) found a similar rotated bedding in the Rebrnice area. There is an active landslide in the central part of the Strane village itself, but the landslide mechanism has not yet been investigated.

Let us take a look at the longitudinal cross-sections 1a and 1b (Fig. 11) before we describe the gravitational structure of Mt. Suhi vrh. The thrust plane is constructed according to the flysch outcrops
Hrušiškega pokrova, prevzela vlogo gravitacijske zdrsne ploskve. Argumenti za tako interpretacijo bodo podani kasneje. V plaziščih Ubeljska stena in Votla stena na površju prevladujejo pobočni grušč in manjši skalni podori. Pomembnejše pa je plazišče Rjava stena, kjer $\mathrm{v}$ severnem delu prevladujejo veliki blokovni zdrsi in podori, v južnem delu pa rotacijski plazovi. Za ilustracijo je na sliki 10 prikazan povratni vpad plasti (335/20) fosilnega gruščnatega rotacijskega plazu nad vasjo Strane. Podobne povratne vpade plasti litificiranih meliščnih zaplat ugotavlja Popit (2017) v zaledju plazov Šumljak na območju Rebrnic. V sami vasi Strane pa obstoja delujoči plaz, ki zajema osrednji del naselja. Mehanizem tega plazu ni raziskan.

Preden opišemo gravitacijsko strukturo Suhega vrha, si moramo ogledati vzdolžna profila Nanosa 1a in 1b na sliki 11. V profilu 1a je narivna ploskev konstruirana po izdankih fliša nad Sv. Brikcijem, ki stoji na višini $960 \mathrm{~m}$, fliš pod Suhim vrhom torej presega višino $1000 \mathrm{~m}$ in se nato spušča proti dnu Rjave stene, kjer dosega višino okoli $850 \mathrm{~m}$. Pri interpretaciji profila so bili odločilni trije elementi zgradbe, na prvem mestu je dejstvo, da v strukturi Votle stene ni videti stopničastega zaporedja normalnih prelomov ali velikih gravitacijskih drsnih ploskev, ki bi pojasnjevale nastanek dolin a, b in c (sl. 8), na drugem mestu je podatek, da ležijo omenjene 


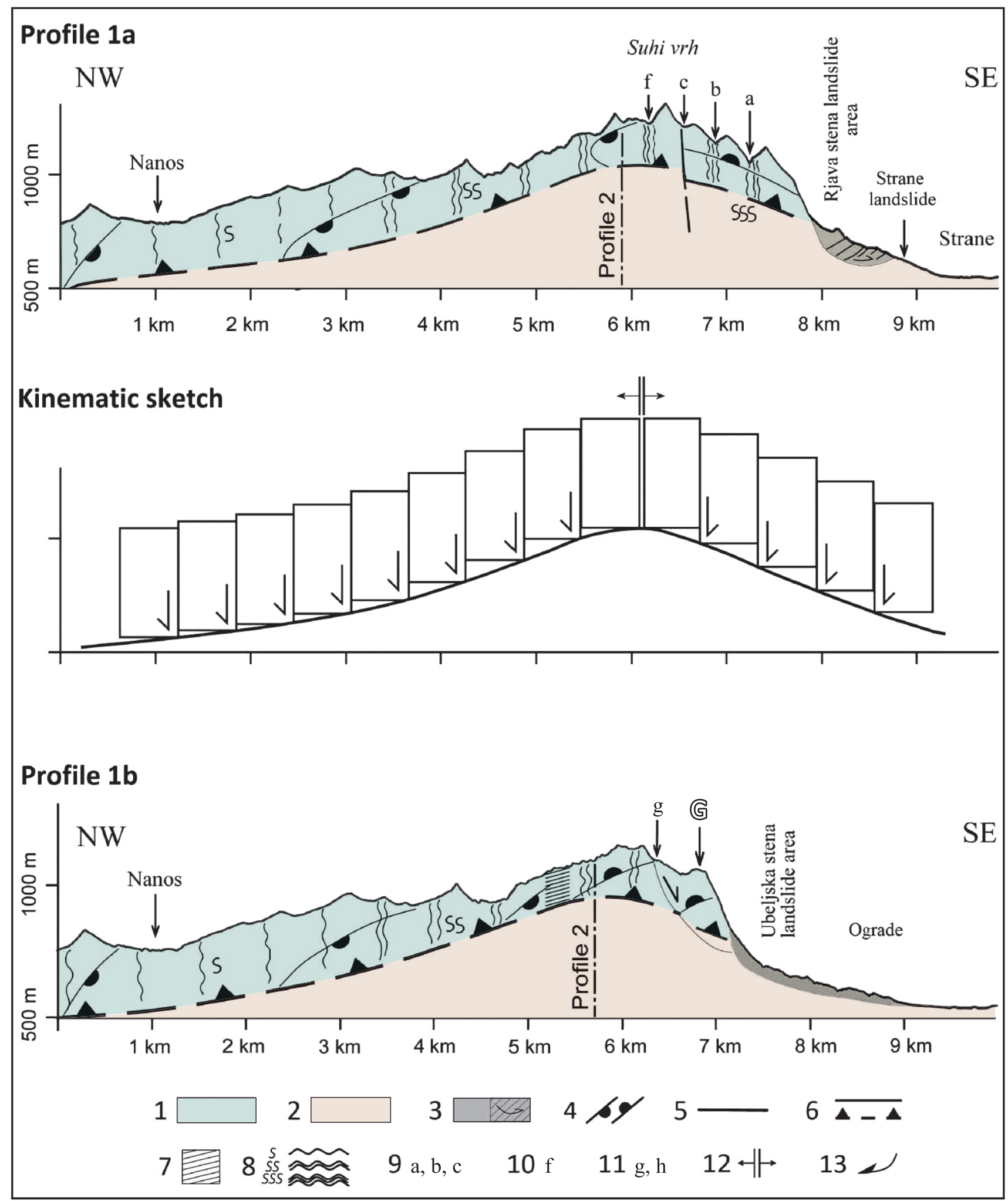

Fig. 11. Longitudinal structural cross-sections of the Mt. Nanos and a kinematic sketch. Profile 1a: Nanos (village) - Mt. Suhi vrh (1313 m) - Rjava stena - Strane (village). Profile 1b: Nanos (village) - »Ubeljska stena« - Ograde (near village Strane). Kinematic sketch of differential offsets of the carbonate micro and macrolithons along regional sub-vertical fractures (strike angle $20^{\circ}-40^{\circ}$ ) above the convexly cambered (bent) thrust plane in the Nanos antiform.

Sl. 11. Vzdolžna strukturna profila Nanosa in kinematska skica. Profil 1a: Nanos - Suhi vrh (1313 m) - Rjava stena - Strane. Profil 1b: Nanos - »Ubeljska stena - Ograde pri Stranah. Kinematska skica diferencialnih premikov karbonatnih mikro in makrolitonov ob regionalnih subvertikalnih razpokah (od $20^{\circ}$ do $40^{\circ}$ ) nad konveksno usločeno krovno narivno ploskvijo nanoške antiforme. 
1 Mesozoic carbonates / mezozojski karbonati

2 Eocene flysch / eocenski fliš

3 Slope scree, rotational landslide / pobočni grušč, rotacijski plaz

4 Bedding: normal, inverse / plasti: normalne, inverzne

5 Fault: RoF - Roček fault, ReF - Reševnik fault / prelom: RoF - Ročkov prelom, ReF - Reševniški prelom

6 Hrušica Nappe thrust plane / narivna ploskev Hrušiškega pokrova

7 Tectonized zone in the core of the recumbent frontal anticline / tektonizirana cona v jedru polegle krovne antiklinale

8 Regional subvertical fractures with $20^{\circ}-40^{\circ}$ strike angle: s - fracture lines without geomorphological response: ss - fractural furrows: sss - razdols / regionalne subvertikalne razpoke smeri $20^{\circ}$ do $40^{\circ}$ : s - razpoklinske linije s slabim geomorfološkim odzivom: ss - razpoklinske linije z močnejšim geomorfološkim odzivom: sss - razdoli

9 Shear razdol / strižni razdol: a, b, c

10 Divergent razdol /razmični razdol: $\mathrm{f}$

11 Marginal trench / robni jarek: g - probable / verjetni, h - inferred / domnevni

12 Divergence area / območje razmikanja

13 Hypothetical gravitational heredital slide along the Reševnik fault in the Rebrnice slope / hipotetični gravitacijski nasledstveni zdrs po Reševniškem prelomu na Rebrnicah

above Sv. Bikcij (St. Brictius) (960 m a.s.l.) in the 1a cross-section. The flysch beneath Mt Suhi vrh is therefore higher than $1000 \mathrm{~m}$ a.s.l. and descends towards the base of the Rjava stena, where it is found at approx. $850 \mathrm{~m}$ a.s.l. Three structural elements are decisive for the cross-section interpretation. The first is the fact that there is no succession of steplike normal faults in the Votla stena structure, nor any large gravitational slip planes to explain the formation of the $a, b$ and $c$ valleys in Figure 8 . The second lies in the fact that these valleys are parallel to the regional NNE - SSW-oriented subvertical fractures rotated in a NW - SE direction; and finally, the fact that the geomorphological responsiveness of this regional fracture system is consistent with the thrust plane morphology, which takes the shape of a convex bulge called the Nanos antiform. The fractures' geomorphologic responsiveness to the thrust plane morphology is reflected in the Lidar-derived image as individual furrows and more or less obvious strings of dolines (the $\mathbf{s}$ fracture lines) that deviate from other doline strings, like those formed along the bedding traces (Fig. 11). The geomorphic response to these fractures is stronger, but less obvious in the area where the Hrušica Nappe thrust plane is steeper, between the village of Nanos and Suhi vrh (1313 m a.s.l.). The geomorphologic response to the bedding of the Lower Cretaceous limestones in the form of step-like valleys is stronger there and thus prevails. The only interruption of individual ridges between these asymmetric valleys seems to represent a geomorphologic response to the NNE - SSW oriented fractures (the ss lines) there (Fig. 11). In the block above the Rjava stena, however, relatively deep, straight symmetric valleys are formed (the sss lines). For the latter, a new term razdol is proposed here. The abbreviated Slovene terms razpoka (Slovene term for fracture) and dol = dolina (valley) are combined into the proposed term razdol. Only razdols have a characteristic shape in the Mt. Nanos area, while more or less doline v smeri sistema regionalnih subvertikalnih razpok SSW-NNE, ki so tu rotirane v smer SW-NE, in nazadnje dejstvo, da je geomorfološka odzivnost omenjenega sistema regionalnih razpok usklajena z morfologijo narivne ploskve, ki ima obliko konveksne izbokline imenovane nanoška antiforma. Geomorfološka odzivnost teh razpok na morfologijo narivne ploskve se kaže tako, da se na širšem območju zaselka Nanos razpoke na lidarju vidne kot posamezne brazde in bolj ali manj očitni nizi vrtač (razpoklinske linije s), ki po usmerjenosti odstopajo od ostalih, npr. razvitih vzdolž plastnatosti (sl. 11). $\mathrm{Na}$ območju, kjer je Hrušiška narivna ploskev strmejša, med zaselkom Nanos in Suhim vrhom $(1313 \mathrm{~m})$ je geomorfološki odziv teh razpok močneje izražen vendar slabše viden, ker je zakrit z veliko močnejšim geomorfološkim odzivom na plastnatost (medplastni zdrsi) spodnjekrednih apnencev v smeri NNW, zato se odraža le kot prekinitev grebenov asimetričnih dolin vzporednih plastnatosti (linije - ss) (sl. 11). V bloku nad Rjavo steno pa se odziv na te razpoke kaže kot simetrične razpoklinsko-korozijske doline (sss) za katere uvajamo novo ime, ki združuje termina razpoka (skrajšano raz) in dolina (skrajšano dol) v nov termin razdol. Na območju Nanosa imajo vzorčno geomorfološko obliko le razdoli, medtem ko so bolj ali manj razviti razpoklinski nizi vrtač slabše vidni in neprimerni za temeljno predstavitev.

Profil 1b kaže razmere v zaledju Ubeljske stene, kjer poteka preko zdrselega bloka G (sl. 8). Razlaga temelji na interpretaciji senčenega modela reliefa izdelanega iz lidarskih podatkov (eVode, 2016). 
developed doline strings along other fracture systems are less pronounced and hence not suitable for comprehensive presentation.

The geological cross-section $1 \mathrm{~b}$ across a gravitationally slided G block (Fig. 8) illustrates the geological structure behind the Ubeljska stena. The explanation is based on the interpretation of a shaded relief model constructed from lidar images (eVode, 2016).

A comparison of the two cross sections (1a and 1b) shows they are identical, except for the missing carbonate cover in the $1 \mathrm{~b}$ cross-section that is still present in the 1a cross-section behind the Votla and Rjava stena. The missing carbonate cover $\mathrm{E}$ of Ubeljska stena gradually disintegrated into slided and collapsed blocks and corroded relatively quickly due to the presence of water.

A simplified kinematic sketch illustrating the relations between the convex shape of the flysch basement beneath the thrust fault and the structural blocks (macrolithons) in the carbonate hanging block is given in Fig. 11. Offsets in the rigid media
Na podlagi primerjave med profiloma $1 \mathrm{a}$ in $1 \mathrm{~b}$ je moč ugotoviti, da sta identična, razlika je le v tem, da v drugem profilu ni več karbonatnega pokrova, ki še obstaja v zaledju Votle in Rjave stene. Tu je postopoma razpadel v plazišče in zaradi prisotnosti vode hitreje korodiral.

$\mathrm{Na}$ sliki 11 je pridana poenostavljena kinematska skica, ki ponazarja odnos med konveksno obliko flišne podlage pod narivno ploskvijo in bloki v karbonatni krovni enoti. Premiki v trdnem mediju so se sproščali na več načinov, ali z zdrsi po posameznih razpokah med mikrolitoni, po snopih razpok med makrolitoni in redkeje po eni zbirni razpoki, ki je postala prelom in prevzela vlogo snopa med makrolitoni. Premiki ob razpokah so povzročili tektonizacijo kamnine zaradi česar je postala korozijsko oslabljena. Razdalja med snopi razpok in zbirnimi razpokami je pogosto sistemska, ker je povezana $\mathrm{z}$ različnimi mehanskimi in prostorskimi pogoji, zato je tudi razdalja med razdoli pogosto enaka (sl. 12).

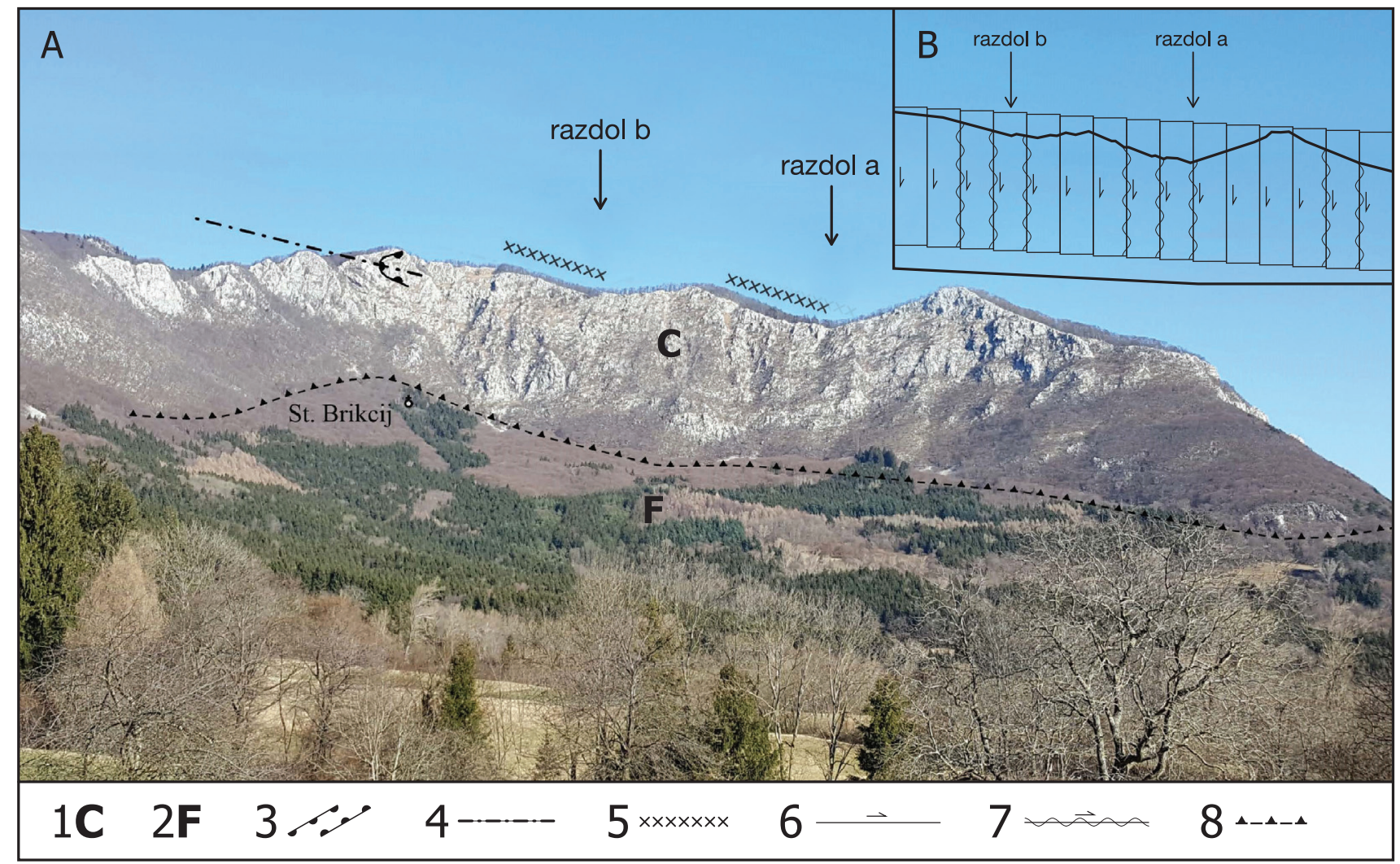

Fig. 12. A. Panoramic view of the Votla stena, B. Kinematic sketch.

Sl. 12. A. Panorama Votle stene, B. Kinematska skica.

1 C - Hrušica Nappe carbonates / karbonati Hrušiškega pokrova

2 F - Flysch of the Snežnik Nappe / fliš Snežniškega pokrova

3 Bedding: normal, inverse / plasti: normalne, inverzne

4 Axial plane of the recumbent frontal anticline / osna ravnina polegle krovne antiklinale

5 Area of intense differential offsets along regional fractures / območje intenzivnejših diferencialnih premikov po regionalnih razpokah

6 Direction of the regional fractures along regional fractures / smer diferencialnih premikov po regionalnih razpokah

7 Direction of intense differential movements along fractures / razpoke z intenzivnejšim diferencialnim premikom

8 Hrušica Nappe boundary / meja Hrušiškega pokrova 


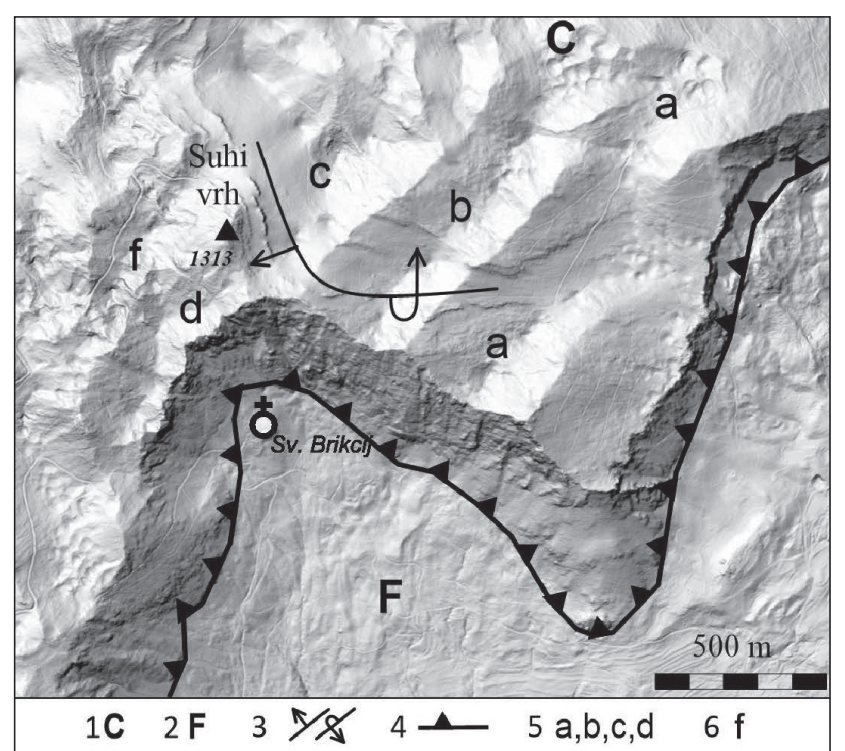

Fig. 13. Razdols morphology.

Sl. 13. Morfologija razdolov.

1 C-Hrušica Nappe carbonates / karbonati Hrušiškega pokrova 2 F - Flysch of the Snežnik Nappe / fliš Snežniškega pokrova 3 Bedding: normal, inverse / plasti: normalne, inverzne

4 Nappe boundary / meja pokrova

5 Shear razdol / strižni razdol: a, b, c, d

6 Divergent razol / razmični razdol: f

(limestone) are realized in several ways - either by slips along individual fractures between microlithons, along fracture sheafs between macrolithons, or less frequently along one collective (cumulative) fracture that became a fault and took over the fracture sheaf role between the macrolithons. The offsets along fractures caused a tectonization of the rock and consequently accelerated corrosion and hence
Na panoramskem posnetku Votle stene (sl. 12) je na levi videti jedro polegle gube, od koder se inverzne plasti vlečejo povprek cele stene, nato razdola a in b, subvertikalne razpoke in snop reaktiviranih razpok $\mathrm{v}$ severozahodnem pobočju vsakega od obeh razdolov.

Razdoli a, b in c so nastali nad jugovzhodnim pobočjem nanoške antiforme, mehanizem nastanka je lepo viden pri razdolih a in b. Njihova smer je enaka smeri razpok in so zaradi tega sorazmerno ravni (sl. 13), v ozkem dnu razdola pa je običajno niz ponorov (sl. 14). Pred seboj imamo strižno razpoklinsko-korozivno dolino ali strižni razdol.

Drugačna je morfološka podoba razdola f, ki se nahaja na vrhu nanoške antiforme (sl. 11, 1a); tu se niso toliko uveljavili gravitacijski diferencialni zdrsi temveč razmikanje in kot posledica ugrezanje makrolitonov, podobno kot $\mathrm{v}$ primeru ugrezanja temena antiklinale. Temu ustreza tudi morfologija tega razdola; njegovo dno je ravno in predstavlja površino ugreznjenega makrolitona, po nastanku enak malemu tektonskemu jarku. Razdol, ki je nastal z ugrezanjem makrolitona (strukturnega bloka) imenujemo razmično razpoklinsko-korozivna dolina ali razmični razdol (sl. 15).

Na sliki 8 je prikazana razporeditev razdolov $\mathrm{a}, \mathrm{b}, \mathrm{c}, \mathrm{d}$ in e, ki so nastali v razpoklinskih sistemih po diferencialnih strižnih premikih in razdol f, ki je razmičnega (divergentnega) nastanka. Poleg tega obstajata še dve, dolini podobni

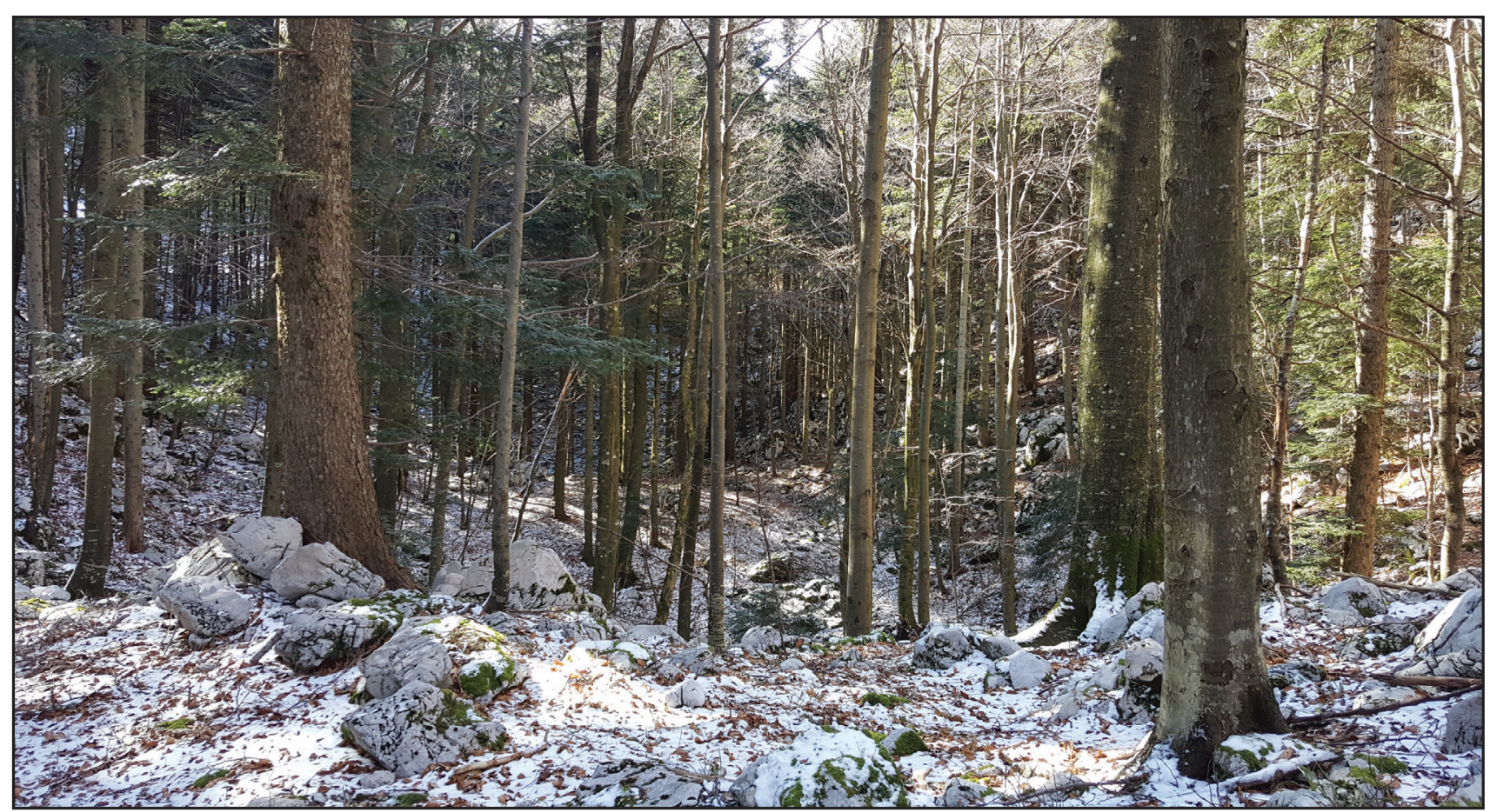

Fig. 14. Shear razdol a. A valley formed in a course of successive shear offsets in a fracture system, enhanced by corrosion. Sl. 14. Strižni razdol a. Razpoklinsko-korozivna dolina nastala pri strižnih sukcesivnih premikih po razpoklinskem sistemu. 
weakened the rock between offset macrolithons. The distance between the fracture sheafs and collective fractures is often systemic, as it is related to various mechanical and spatial conditions, and thus frequently equidistant from each other (Fig. 12).

The core of a recumbent fold with its inverse strata along the entire wall, together with two razdols are visible in the Votla stena panoramic photograph (Fig. 12), along with the subvertical fractures and finally a sheaf of tectonized fractures on the NW slope of both razdols.

Razdols a, b and c were formed above the SW slope of the Nanos antiform, and the formation mechanism is obvious in the a and b razdols, as their orientation is parallel to the fractures which is why they are relatively straight (Fig. 13) and usually host a string of sinkholes along the narrow bottom (Fig. 14). This type of razdol formed along either a single (leading) or multiple shear fractures, hence the term shear razdol.

The morphology of razdol $\mathrm{f}$ is somewhat different (Fig. 11, 1a), as it was formed on the crest of the Nanos antiform. Divergent offsets and the consequential subsidence of the macrolithons prevail in this type of razdol, much like a crestal collapse or a miniature tectonic graben. The base of the shear razdol is therefore flat, as it represents the subsided microlithon upper surface. This type of razdol is referred to as a divergent razdol (Fig. 15).

A disposition of the $a, b, c, d$, and e shear razdols formed in the fracture systems by subsidence along the shears between the microlithons and the divergent razdol $\mathrm{f}$ is presented in Figure 8. Features similar to valleys $h$ and $g$ formed outside the regional (NNE - SSW) fracture system exhibit signs of mass movement. The $h$ valley's circular shape resembles a valley between a head scarp with a shear plane in the hinterland and the reverse slope of the rotated slump blocks. The structural block south-east of the inferred head scarp (h) is 50 to $100 \mathrm{~m}$ lower from the block that lies to the north-west and characteristically deformed. The bedding geometry changes several times across the presumably slumped block resembling multiple rotated slump blocks, while north-west of the inferred head the scarp bedding is uniform. In the case of the $g$ valley, a gravitational offset of the G block is evident from its protruding position. The first case (g) is inferred, the other (h) is probable. Not only the G block protrudes, but the $\mathrm{E}$ block also protrudes from the Ubeljska stena scarp. It seems that differential offsets along the fracture system in which the e valley formed took place first, and later a more pronounced gravitational offset proceeded along one of the fractures or the fracture sheaf (Fig. 8).

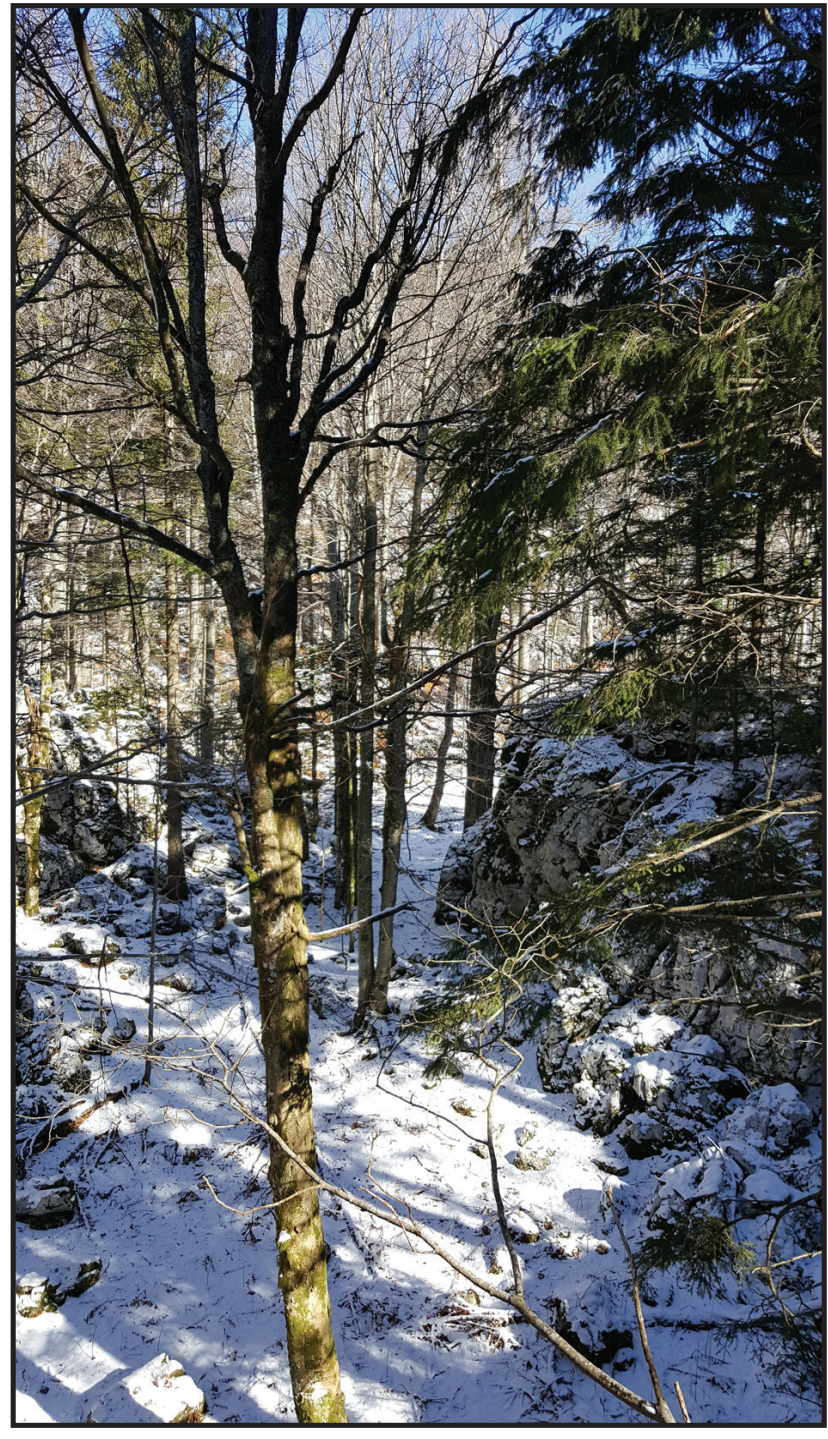

Fig. 15. Divergent razdol f. A valley formed due to divergent offsets in a fracture system enhanced by corrosion. A flat valley bottom and steep side walls suggest subsidence of the intermediate block (macrolithon).

Sl. 15. Razmični razdol f. Razpoklinsko-krozivna dolina nastala zaradi razpiranja po razpoklinskem sistemu. Ravno dno in bočne stene nakazujejo, da se je vmesni blok (makroliton) ugreznil.

tvorbi h in g, ki kažeta na gravitacijska zdrsa izven regionalnega sistema razpok (NNE - SSW), v prvem primeru kaže na to njena polkrožna oblika, ki domnevno predstavlja robni jarek in v zaledju drsno ploskev rotacijskega plazu. Blok jugovzhodno od domnevnega robnega jarka $h$ leži okoli 50 do $100 \mathrm{~m}$ nižje od tistega na severozahodu poleg tega je jugovzhodni blok značilno prizadet, tu se lega plasti večkrat spremeni, kar kaže na obstoj različnih manjših blokov, medtem ko imajo plasti severozahodno od tod enotno smer. V primeru domnevnega robnega jarka g je zdrs nakazan z izstopajočo lego bloka G. Prvi primer (g) je domneven, drugi (h) pa verjeten. Poleg bloka G izstopa tudi blok E, kjer izgleda, da je prišlo najprej do diferencialnih premikov po sistemu razpok po katerih je nastal razdol e, 
Razdols d and e and a trench (valley) g beneath the head scarp are remnants of the gravitational structures, much like those behind the Rjava and Votla stena. Geological conditions in the Ubeljsko steephead were identical to those behind the Rjava and Votla stena before the carbonate cover disappeared due to gravitational, corrosive and denudational processes, which were the same as those observed at the Rjava stena landslide area.

Gravitational phenomena comprising a to $\mathrm{f}$ razdols and both $\mathrm{g}$ and $\mathrm{h}$ marginal trenches belong to the Suhi vrh gravitational structure. Razdols aren't formed due to classical slope processes, but as part of processes related to gravity.

Let us look at transverse cross-section 2 in Fig. 16 in order to complete the image of the structure of the SE part of Mt. Nanos. The thrust plane position is taken from the $1 \mathrm{a}$ and $1 \mathrm{~b}$ cross-sections; however, difficulties arise in the interpretation related primarily to its dip rather than elevation above the village of Žvanuti. There is no (karstic) spring to drain the karstic water from Mt. Nanos between Razdrto and Vipava. This fact is formally supported by the $45 / 20$ thrust plane dip in the outcrop at $540 \mathrm{~m}$ a.s.l. in the roadcut of the $4^{\text {th }}$ serpentine (from above) of the road to Mt. Nanos, about $3 \mathrm{~km}$ NW of cross-section 2 . No other relevant data exists on the area between the described outcrop and Razdrto. The absence of karstic (there are springs and streamlets on the SW slope of Mt. Nanos, but these only drain the meteoric water from the slope scree) springs on the SW slope of Mt. Nanos does not correspond to the Nanos antiform beneath Suhi vrh (1313 $\mathrm{m}$ a.s.l.); as a result, the only available solution lies in the existence of the 210/60 Reševnik fault above Razdrto (Figs. 8 and 9). The subsided SW block makes it a seemingly normal fault. pozneje pa tudi do močnejšega gravitacijskega zdrsa po eni od razpok ali snopu razpok (sl. 8).

Razdola d in e ter »robni jarek« g so ostanki gravitacijskih struktur, ki so enake tistim v bloku za Votlo in Rjavo steno. Pred nastankom Ubeljskega zatrepa so tu obstajale enake razmere na celotni površini zatrepa, karbonatni pokrov je tu izginil zaradi gravitacijskih, korozivnih in denudacijskih procesov, ki so bili taki kot jih danes opazujemo na plazišču Rjava stena.

Gravitacijske strukture, ki zajemajo razdole od a do $\mathrm{f}$ in oba »robna jarka $\mathrm{g}$ in $\mathrm{h}$ pripadajo gravitacijski strukturi Suhega vrha. Razdoli niso nastali zaradi klasičnih pobočnih procesov, gre pa za pojave, ki so povezani z gravitacijo.

Da bi zaokrožili predstavo o zgradbi jugovzhodnega dela Nanosa, si oglejmo še prečni profil 2 na sl. 16, Lega krovne narivne ploskve je povzeta po profilih 1a in 1b, težave pa nastopijo pri interpretaciji njene lege nad Žvanuti na območju Rebrnic. Vprašljiva ni njena višinska kota temveč vpad; v čelu Hrušiškega pokrova od Razdrtega do izvira Vipave ni nikjer izvira, ki bi odvajal kraško vodo iz Nanosa, formalno je ta podatek podprt z vpadom narivne ploskve $v$ golici na četrti serpentini nanoške ceste od zgoraj navzdol, ki znaša 45/20 in se nahaja okoli $3 \mathrm{~km}$ severozahodno od profila 2. Od omenjene golice do Razdrtega ni ustreznega podatka. Odsotnost kraških izvirov se ne ujema z antiformo pod Suhim vrhom, v pobočju Rebnic so namreč le potočki, ki odvajajo meteorno vodo. V tem trenutku vidimo rešitev problema $\mathrm{v}$ obstoju Reševniškega preloma 210/60 nad Razdrtim (sl. 8 in 9), ob katerem je jugozahodno krilo spuščeno, zaradi česar daje videz normalnega preloma. Vendar ponujajo razmere na območju Razdrtega tudi drugačno razlago, zato postavljamo domnevo,

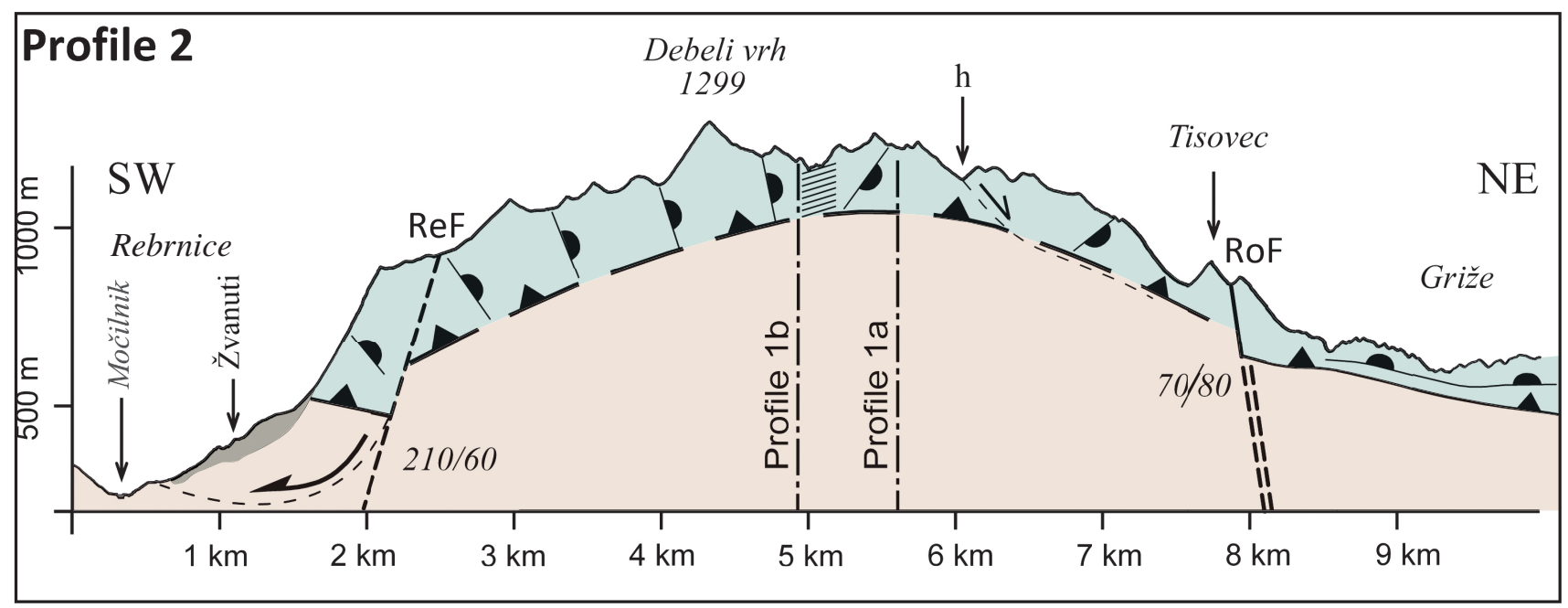

Fig. 16. Transverse structural cross-section 2: Žvanuti - Debeli vrh - Tisovec - Griže. Key in Fig. 11.

Sl. 16. Prečni strukturni profil 2: Žvanuti - Debeli vrh - Tisovec - Griže. Legenda na sl. 11. 
However, the geological conditions of the Razdrto area offer an alternative explanation, in which the Reševnik fault planes took over the rupture surface role in the sub-recent erosional-denudational environment. This assumption is supported by a 210/50 fault plane within the Reševnik fault zone. According to the spatial criterion this fault plane could act as a rupture surface of a large Reševnik fossil rotational landslide superimposed by the recent Razdrto translational landslide (Placer, 2006). The Reševnik rotational landslide is confirmed by the reversely tilted flysch beds.

As the Reševnik fault has not been mapped and followed on the surface due NW, only a hypothetical solution is provided in cross-section 2 (Fig. 16). Here, the Reševnik fault is only extrapolated some $3.5 \mathrm{~km}$ due NW. A normal fault could not have caused a backtilting of the thrust plane, but only a rotational landslide could have done so. Only specifically targeted research could provide the answer as to whether one or more fossil gravitational phenomena occurred in the Rebrnice slope.

\section{A Nanos antiform}

Knowledge of the Hrušica thrust plane morphology is important in order to gain an understanding of the structural, geomorphologic, and hydrologic issues of the area considered here and in the wider area as well. The interpretation of its morphology - structural map of the Nanos antiform (Fig. 17) - is based on the course of its boundaries and structural cross-sections (1a, $1 \mathrm{~b}$ and 2 ).

The internal structure of the structural block behind the Votla and Rjava stena is reflected in the Votla stena structure (cross-section 1a in Figs. 11 and 12). It has been established that the Hrušica Nappe thrust plane inclination towards the Postojna basin (SE) is not a consequence of rotational or translational mass movements. It is a differential uplift of the Nanos antiform that triggered differential offsets along the discontinuous SW - NE (SSW $\mathrm{NNE}$ ) fracture system. The interpretation is reliable only near the nappe boundary. Beneath the carbonate nappe, the interpretation is based on the coincidence of the anomaly apex and Mt. Suhi vrh (1313 m a.s.l.), the highest peak of Mt. Nanos. Based on this coincidence, it is inferred that the most uplifted parts of Mt. Nanos between Mt. Suhi vrh (1313 m a.s.l.) and Mt. Debeli hrib (1209 m a.s.l.) along the $330^{\circ}$ course may be related to this deformation as well. This trend is subtly predented with the Nanos antiform longitudinal axis trend seen in Figure 16.

The isolines course in the Rebrnice slope is based on the cross-section 2 interpretation (Fig. 16). Construction of the $700 \mathrm{~m}, 800 \mathrm{~m}$ and the $900 \mathrm{~m}$ isolines da je prelomna ploskev tega preloma v subrecentnih erozijsko-denudacijskih pogojih postala ploskev gravitacijskega zdrsa. To domnevo utemeljujemo s prelomno ploskvijo znotraj cone Reševniškega preloma $210 / 50$, ki bi po prostorskem kriteriju lahko bila nosilka velikega fosilnega rotacijskega plazu Reševnik na katerem leži recentni planarni plaz Razdrto (Placer, 2006). Na rotacijski plaz Reševnik kažejo povratno zasukane flišne plasti.

Reševniški prelom ni bil kartiran in sleden na površju proti severozahodu, zato je mogoče podati le hipotetično rešitev, kot je prikazana v profilu 2 (sl. 16). Tu je Reševniški prelom ekstrapoliran okoli $3,5 \mathrm{~km}$ proti severozahodu, normalni premik ob prelomu ne bi mogel zasukati narivne ploskve v nasprotno smer, to se je lahko dogodilo le zaradi fosilnega rotacijskega plazu. Ali obstoja na Rebrnicah eden ali več fosilnih gravitacijskih pojavov, ni mogoče ugotoviti brez usmerjene raziskave.

\section{Nanoška antiforma}

Poznavanje morfologije narivne ploskve Hrušiškega pokrova je pomembno za razumevanje strukturnih, geomorfoloških in hidroloških vprašanj obravnavanega in širšega prostora. Interpretacija morfologije narivne ploskve sloni na poteku meje pokrova in na strukturnih profilih $1 \mathrm{a}, 1 \mathrm{~b}$ in 2 , rezultat je strukturna karta nanoške flišne antiforme (sl. 17).

Notranja zgradba strukturnega bloka za Votlo in Rjavo steno se kaže v zgradbi Votle stene (profil 1a na sl. 11 in 12). Ugotovljeno je, da vpad narivne ploskve proti Postojnski kotlini ni posledica rotacijskega ali drugačnega plazenja, temveč usločenja nanoške antiforme, kar je povzročilo nastanek diferencialnih premikov po diskontinuitetah razpoklinskega sistema SW-NE (SSW-NNE). Interpretacija je zanesljivejša le blizu meje pokrova, od tu pa je razdeljena na del pod karbonatnim pokrovom in na del nad sedanjim površjem zahodnega dela Postojnske kotline. Interpretacija poteka narivnice pod karbonatnim pokrovom temelji na sovpadanju vrha anomalije in Suhega vrha (1313 m), ki je najvišji vrh Nanosa. Na podlagi tega sklepamo, da so najvišji deli Nanosa proti Debelemu hribu (1209 m), v smeri $330^{\circ}$, lahko povezani s to deformacijo. Ta smer je rahlo nakazana z obliko antiforme. Potek izolinij na Rebrnicah sloni na interpretaciji profila 2 (sl. 16).

Izolinije 900, 800 in 700 nad zahodnim delom Postojnske kotline sledijo razmeram na območju Votle in Rjave stene, kjer vpadajo proti kotlini. 


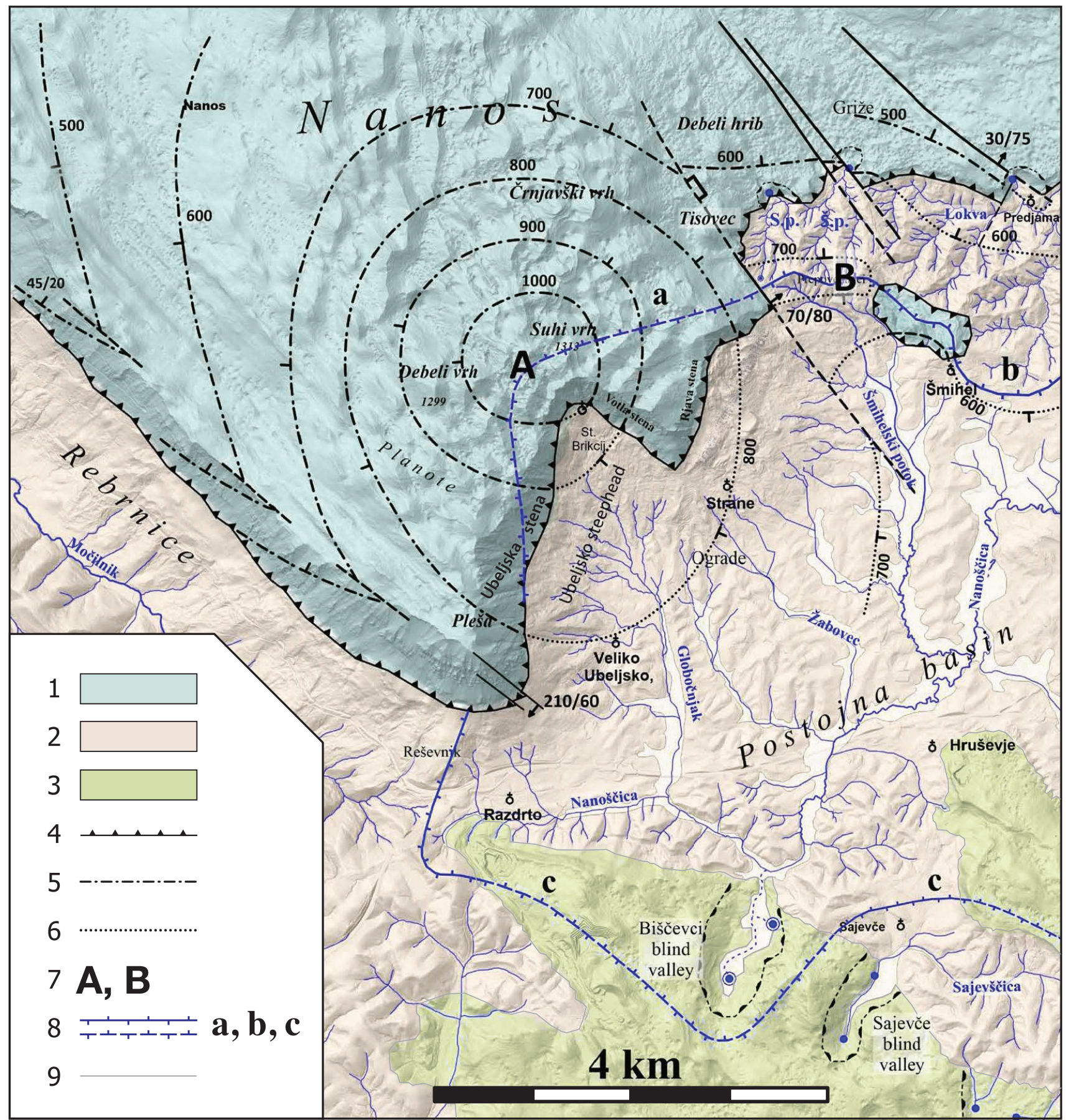

Fig. 17. Structural sketch of the Nanos antiform.

Sl. 17. Strukturna skica nanoške antiforme.

1 Mesozoic carbonates of the Hrušica Nappe / mezozojski karbonati Hrušiškega pokrova

2 Eocene flysch of the External Dinaric Imbricated Belt and of the Snežnik Nappe / eocenski fliš Zunanjedinarskega naluskanega pasu in Snežniškega pokrova

3 Mezozoic and Paleogene carbonates of the External Dinaric Imbricated Belt / mezozojski in paleogenski karbonati Zunanjedinarskega naluskanega pasu

4 Hrušica Nappe boundary / meja Hrušiškega pokrova

5 Thrust plane isoline beneath the nappe / izolinija narivne ploskve pod krovno enoto

6 Thrust plane isoline above the surface / izolinija narivne ploskve nad sedanjim površjem

7 Nanos antiform / nanoška antiforma: A - antiform apex (St. Brictius ridge) / vrh antiforme (hrbet Sv. Brikcija), B - Šmihel ridge / šmihelski hrbet

8 Current Adriatic - Black Sea watershed divide / sedanja razvodnica med jadranskim in črnomorskim povodjem: a - section under the Hrušica Nappe / odsek pod Hrušiškim pokrovom, b - section in the Šmihel (village) area / odsek na območju Šmihela, c - section east of Razdrto (village) / odsek vzhodno od Razdrtega

9 Geological boundary / geološka meja 
above the western part of the Postojna basin follows the conditions in the Votla and Rjava stena, where the thrust plane dips towards the basin. In the Šmihel area NE of the Roček fault (70/80) the interpretation is based on the distribution of ponors (sinkholes) W of Predjama and the Šmihel (tectonic) klippe. The thrust plane lies partly below and partly above the $600 \mathrm{~m}$ isoline, while the $700 \mathrm{~m}$ isoline definitively appears near the ridge between Prepovedanci and Praprotniki, just above the $700 \mathrm{~m}$ a.s.l. The described features indicate the existence of a ridge - here called the Šmihel ridge - as part of the Nanos antiform (Fig. 17, B).

When introducing the term Šmihel ridge we must also name the main part of the Nanos antiform for purposes of clearer communication, which is called the Sv. Brikcij ridge or Bric's ridge (Fig. 17, A). The Nanos antiform determines the Adriatic - Black Sea watershed divide in the western part of the Postojna basin (Fig. 17, 8a, 8b). The watershed divide course in the southern part of the Postojna basin east of the village of Razdrto was established as a result of deformations younger than the Nanos antiform S and SE of the Hrušica Nappe (Fig. 17, 8c).

\section{Relief and hydrographic network evolution}

The formation and degradation (erosion) of both ridges in the Nanos antiform had a fundamental impact on the morphology of the hydrographic network in the western part of the Postojna basin (Fig. 17). The oldest landforms that are still recognizable arose when the Hrušica Nappe still covered the western part of the Postojna basin and its southern boundary extended to the Razdrto Hruševje line. Meteoric water was drained vertically through a fractured and karstified limestone nappe to reach a southward-tilted thrust plane. The water formed carstic caves just above the impermeable flysch basement and flowed due south. The springs were aligned along the nappe boundary between Razdrto and Hruševje. After a short course over flysch the water carved two blind valleys due south, the Biščevci and Sajevče valleys. The surface above the blind valleys stands at 650 to $700 \mathrm{~m}$ a.s.l., and the valley bottoms out at about $550 \mathrm{~m}$ a.s.l. or $20 \mathrm{~m}$ above today's Nanoščica Creek valley. The Biščevci blind valley is $1500 \mathrm{~m}$ long and up to $500 \mathrm{~m}$ wide. The valley bottom is covered by fluvial deposits several meters thick of flysch provenance. Today, the Biščevci valley is a relict blind valley, as the hydrological conditions south-eastward in the karst have changed radically. After rainfall, the water springs from the Biščevci valley and flows due north as a heavy stream into the Nanoščica. When
Na območju Šmihela na severovzhodni strani Ročkovega preloma (70/80), sloni interpretacija na podatkih meje pokrova $\mathrm{v}$ pasu ponikalnic in Šmihelske tektonske krpe. Ta leži nekaj pod in nekaj nad izohipso 600, izohipsa 700 pa vsekakor poteka okoli grebena med Prepovedanci in Praprotniki, ki je nekaj višji od $700 \mathrm{~m}$. To kaže na obstoj hrbta, ki je del nanoške antiforme. Imenujemo ga šmihelski hrbet (sl. 17, B).

Ob uvedbi termina šmihelski hrbet je zaradi lažjega sporazumevanja potrebno poimenovati tudi glavni del nanoške antiforme (sl. 17, A), imenujemo ga hrbet Sv. Brikcija ali bricov hrbet. Razvodnico med jadranskim in črnomorskim povodjem v zahodnem delu Postojnske kotline določa nanoška antiforma (sl. 17, 8a, 8b). Potek razvodnice na jugu kotline, od Razdrtega proti vzhodu, pa se je oblikoval zaradi deformacij ozemlja južno in jugozahodno od pokrova. Te so mlajše od nanoške antiforme (sl. 17, 8c).

\section{Razvoj reliefa in hidrografske mreže}

Nastanek in razgradnja obeh hrbtov nanoške flišne antiforme sta vplivali na današnjo oblikovanost hidrografske mreže in reliefa $\mathrm{v}$ zahodnem delu Postojnske kotline (sl. 17). Najstarejše danes še zaznavne reliefne oblike so nastale, ko je rob Hrušiškega pokrova v zahodnem delu kotline segal še več kilometrov južneje, nekako do črte Razdrto - Hruševje. Padavinska voda je skozi razpokan in zakrasel apnenčasti pokrov vertikalno odtekala do nagnjene narivne ploskve. Tik nad njo je v apnencih oblikovala jame, ter nad nepropustno flišno podlago odtekala proti jugu. Izviri so bili razporejeni ob robu pokrova na črti med Razdrtim in Hruševjem. Izvirna in površinska voda s fliša je nato po kratkem toku po flišu oblikovala dve proti jugu usmerjeni slepi dolini, Biščevce in Sajevško dolino. Dolini sta vrezani v površje, ki je na višinah med 650 in $750 \mathrm{~m}$. Dna slepih dolin sta na nadmorski višini okrog $550 \mathrm{~m}$, oziroma $20 \mathrm{~m}$ nad sedanjo dolino Nanoščice. Slepa dolina Biščevci je dolga $1500 \mathrm{~m}$ in do $500 \mathrm{~m}$ široka. Dno doline pokrivajo več $\mathrm{m}$ debele plasti fluvialnih sedimentov, ki jih je vanjo naplavila ponikalnica $s$ fliša. Danes so Biščevci reliktna slepa dolina, saj so se hidrološke razmere $\mathrm{v}$ krasu jugozahodno od tod povsem spremenile. V dolini po dežju izvira voda, ki teče proti severu in se kot močan potok izliva v Nanoščico, ob nizkem vodostaju pa se voda skozi apnenec kraško preceja proti Sajevški slepi dolini. Sajevško slepo dolino je po dimenzijah sodeč oblikovala večja voda, verjetno Šmihelski potok. Danes pa v njej ponika le 
water levels are low, however, it seeps through the karstified limestone towards the Sajevče blind valley. In view of its size, the Sajevče valley must have been formed by a relatively large stream, probably the Šmihel creek. Today, however, only a small streamlet drains the surface water from the flysch and sinks into the valley. The streamlet sinks in the cave of Markov spodmol, part of the Vodna jama $\mathrm{v}$ Lozi water cave that stretches $6 \mathrm{~km}$.

The Biščevci and Sajevče blind valleys are the largest blind valleys in the Postojna basin. Their position suggests the primal drainage direction of the western part of the Postojna basin due south. According to their size and shape the southward directed stream courses with a low gradient in the karstic part lasted a relatively long time. The levelled Slavenski ravnik and a preserved unroofed cave there at $600 \mathrm{~m}$ a.s.l. also support this interpretation.

The Hrušica Nappe southern front withdrew northward rather quickly due to rockfalls and landslides, and underground drainage contributed greatly to the withdrawal as well. The carbonate cover was undermined and disintegrated rather quickly, as karstic caves were formed along the thrust plane and underground rivers eroded the flysch in the base. Heavily disintegrated and karstified limestone cover there accelerated karstic denudation, as denudation is far more effective in the fractured and tectonized limestone, rockfalls and slope screes. The underground drainage pattern formed along the thrust plane was reproduced down into the flysch and established the courses of the present Globočnjak, Žabovec and Šmihel creek valleys due south.

Only a very small amount of water is drained from the carbonate cover into the Ubeljsko steephead, hence the indistinct fluvial relief and far slower degradation of the thrust margin above. The Hrušica Nappe margin within the Bric's ridge already lies north of its highest part. The surficial watershed divide runs between the Nanoščica creek tributaries and the streams that flow due north and sink under the nappe margin west of Predjama; the creeks are as follows: Stranske ponikve (S.p. in Fig. 17), Šmihelske ponikve creek (̌̌.p. in Fig. 17), and Lokva, all part of the Vipava River catchment area. The elevations of their sinkholes, as determined by the thrust plane are: $608 \mathrm{~m}$ a.s.l, $600 \mathrm{~m}$ a.s.l., and $462 \mathrm{~m}$ a.s.l., respectively. The formation of the valleys was also influenced by the shape and inclination of the thrust plane. The fluvial relief is more pronounced here because it is younger, due to the steeper thrust plane, and the high gradient in the karst. majhen potok, ki krajevno zbira vodo na flišu. Potok ponika v jami Markov spodmol, ki je del $6 \mathrm{~km}$ dolge Vodne jame v Lozi.

To sta največji slepi dolini v Postojnski kotlini. Kažeta na prvotno smer odtekanja zahodnega dela kotline proti jugu. Po velikosti ter obliki dolin je trajal odtok v to smer dolgo časa, gradient v krasu pa je bil majhen. O tem priča uravnava Slavenskega ravnika južno od tod in $\mathrm{v}$ njem ohranjena $3 \mathrm{~km}$ dolga brezstropa jama na višini okrog $600 \mathrm{~m}$.

Južni rob Hrušiškega pokrova se je zaradi podorov in plazov relativno hitro umikal proti severu. $\mathrm{K}$ umikanju je močno prispevala podzemna drenaža. Ob narivni ploskvi so se oblikovale jame, jamske reke pa so erodirale fliš v podlagi. To je spodjedalo in destabiliziralo karbonatni pokrov, ki se je zaradi tega hitreje podiral, pospeševalo pa je tudi kraško denudacijo, ki je veliko hitrejša na pretrtih in porušenih apnencih, podorih in meliščih. Vzorec jamske podzemne drenaže, ki se je oblikovala ob narivni ploskvi pa se je reproduciral navzdol v flišne kamnine in zasnoval potek današnjih dolin Globočjaka, Žabovca in Šmihelskega potoka proti jugu.

Ker sega Ubeljski zatrep skoraj do najvišjega dela bricovega hrbta nanoške antiforme, se danes proti njemu ob narivni ploskvi izceja le malo vode iz apnencev. Zato je fluvialni relief na pobočjih neizrazit, upočasnilo pa se je tudi rušenje apnenčastega narivnega roba.

Rob hrušiškega nariva v območju šmihelskega hrbta leži že severno od njegovega najvišjega dela. Tu poteka površinska razvodnica med pritoki Nanoščice in potoki, ki tečejo proti severu in ponikajo pod robom nariva zahodno od Predjame. To so potoki Stranske ponikve (oznaka S.p. na sl. 17), Šmihelske ponikve in Lokva, ki pripadajo povodju Vipave. Višine ponorov, ki jih določa narivna ploskev, so $608 \mathrm{~m}, 600 \mathrm{~m}$ in $462 \mathrm{~m}$. Tudi na oblikovanje dolin potokov je vplivala oblika in pa vpad narivne ploskve. Fluvialni relief je tu bolj izrazit zaradi manjše starosti, večjega naklona narivnice in velikega gradienta v krasu.

Nastajanje obeh hrbtov nanoške flišne antiforme je potekalo sočasno z oblikovanjem reliefa $\mathrm{v}$ zahodnem delu Postojnske kotline. Po tektonskem dvigu območja slepih dolin Biščevci in Sajevške doline, se je Nanoščica preusmerila proti vzhodu v ponorno cono pri Postojnski jami, kjer so ponori na višini $510 \mathrm{~m}$. Odtok proti severu ji je preprečil šmihelski hrbet, ki ima smer zahod-vzhod. 
Both ridges in the Nanos antiform formed simultaneously with the formation of the relief in the western part of the Postojna basin. After the tectonic uplift of the Biščevci and Sajevče blind valleys area the Nanoščica creek shifted its course to the west into a ponor (sinkhole) zone at Postojnska jama cave at $510 \mathrm{~m}$ a.s.l. as the $\mathrm{E}-\mathrm{W}$ trending Šmihel ridge restrained its course due north.

The three-dimensional elevation model of the Nanos southeastern slope in Figure 18 is somewhat distorted, nevertheless the geomorphologic features are still well expressed. Ubeljsko steephead in the first plan is bounded by the Ubeljska stena and Votla stena. Razdols a and b are well exposed parallel to the Rjava stena, behind the Votla stena. The difference between the landslide area below the Ubeljska stena and Votla stena covered by the slope scree differ significantly from the landslide area below the Rjava stena composed of multiple slided rotational blocks.

Šmihel ridge, hosting the Black Sea - Adriatic watershed is visible in the north-eastern corner of the elevation model. Streams on its northern
Tridimenzionalni višinski model jugovzhodnega pobočja Nanosa na sliki 18 je nekoliko popačen, vendar so geomorfološke značilnosti lepo vidne. V ospredju izstopa Ubeljski zatrep, ki ga zapirata Ubeljska in Votla stena. Za Votlo steno in vzporedno z Rjavo steno, sta lepo vidna razdola a in b. Opazna je razlika med plaziščem pod Ubeljsko in Votlo steno, na katerem je pretežno pobočni grušč in plaziščem pod Rjavo steno, ki ga sestavlja več rotacijskih blokovnih zdrsov.

V severnem kotu modela je viden šmihelski hrbet po katerem teče razvodnica med jadranskim in črnomorskim povodjem. Potoki na njegovi severni strani ponikajo pod Hrušiški pokrov, kar je pogojeno s hrušiško sinformo, nasprotno pa ni v območju nanoške antiforme nobenega ponora, tu vse vode odtekajo stran od njenega vrha, ki se nahaja za dnom Ubeljskega zatrepa. Popačenje modela je krivo, da ta značilnost ni opazna.

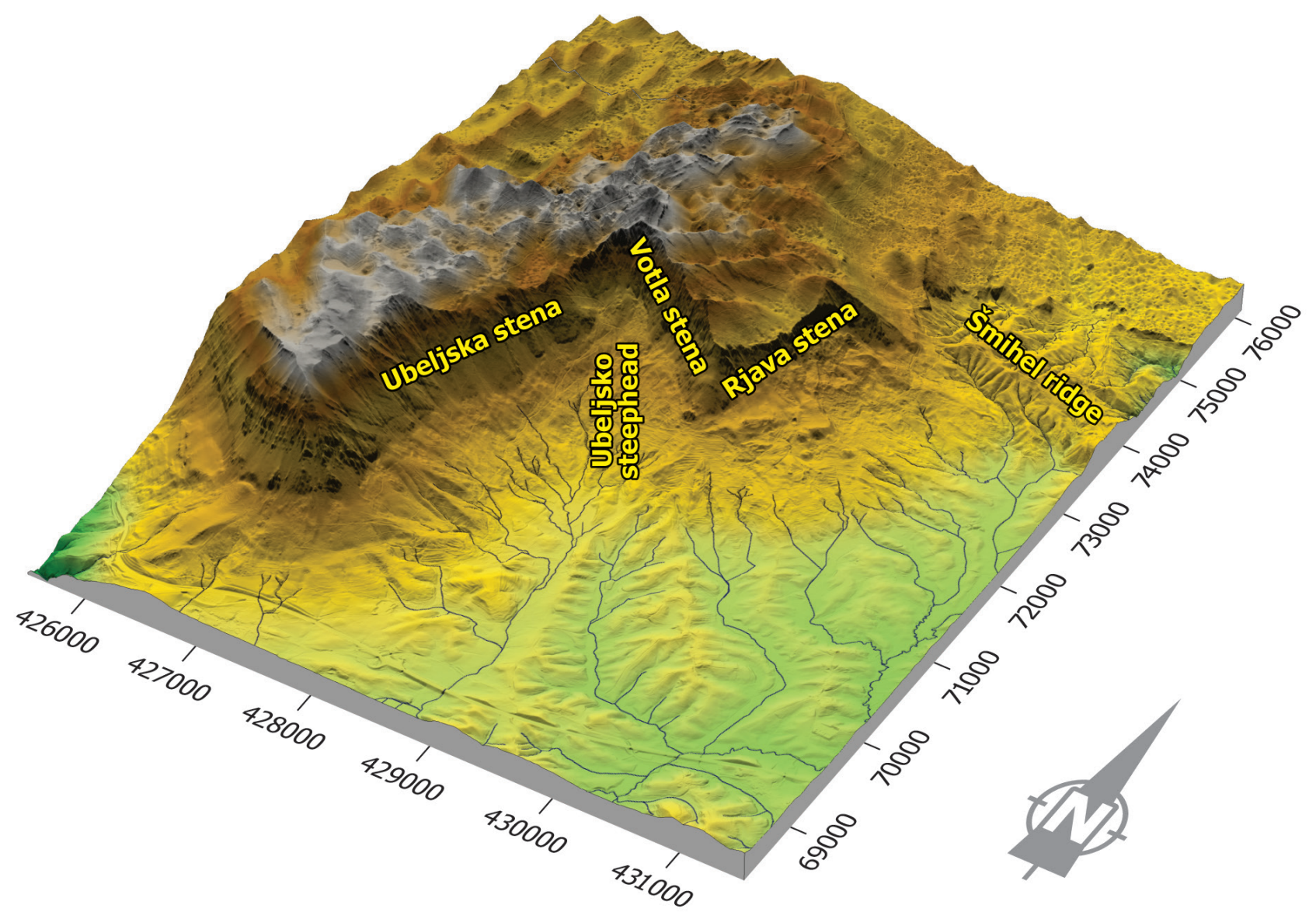

Fig. 18. Three-dimensional view on the southeastern part of Mt. Nanos and of the eastern part of the Postojna basin. Sl. 18. Tridimenzionalni pogled na jugovzhodno pobočje Nanosa in vzhodni del Postojnske kotline. 
side are sinking under the Hrušica thrust due to Hrušica synform and there is no sinkhole in the Nanos antiform area and all the waters run away from its summit behind the base of the Ubeljsko steephead. The described morphologic feature is obscured by the distortion of the elevation model.

\section{Conclusion}

Gravitational phenomena along the SE margin of Mt. Nanos are understood as the degradation of the lateral Hrušica Nappe boundary and its retreat due NE and N. The Suhi vrh gravitational zone in the southeastern flank of the Hrušica Nappe (Fig. 1, b) differs in its mechanism from the landslides in the zone of large gravitational phenomena in the Trnovo Nappe south-eastern block (Fig. 1, a), and the Trnovo and Hrušica Nappe Thrust Fronts (Fig. 1).

The Suhi vrh gravitational area (Fig. 1, b) formed due to an antiform uplift in the frontal part of the Hrušica Nappe and its flysch basement with it. Differential gravitational offsets along a system of sub-vertical regional fractures of the SSW - NNE trend manifested as a result of this antiform uplift. These offset kinematics correspond to the internal rotation of blocks and differ from the classical gravitational mass movements in the landslide areas beneath the Ubeljska, Votla and Rjava stena.

The Ubeljsko steephead was formed due to the degradation of the Suhi vrh gravitational structures by classical rockfalls, landslides and denudational processes. A similar scenario takes place in the preserved part of the Suhi vrh structure behind the Votla and Rjava stena, where mass movements undermine the Rjava stena cliff. Here, the denudational process started later, as the nappe thrust front retreats due $\mathrm{NE}$.

The formation of the differential offsets described in the Nanos antiform (Fig. 11) is inhibited in the Črni školj and Mali Modrasovec area (Fig. 1, a; Fig. 2) despite a well-developed system of regional subvertical NNE - SSW trending fractures, as the bulge of a flysch antiform behind the Trnovo Nappe Thrust Front is barely noticeable. Only classical mass movement types are present there. From the regional point of view it is important, however, that the antiform considered here lies NW of the Nanos antiform, so we can conclude that it represents its structural continuation or its distant spatial repetition. At this point it is reasonable to introduce the term "Čaven antiform" in order to distinguish it from the Nanos antiform.

Large fossil rotationallandslides in the Snežnik Nappe Thrust Front, the inferred landslide at Petelinje mlake (Fig. 1, c) and the confirmed Ilirska

\section{Sklep}

Gravitacijske pojave ob jugovzhodnem robu Nanosa in Hrušice razumemo kot rušenje bočne meje Hrušiškega pokrova in njeno pomikanje proti severovzhodu in severu. Gravitacijsko območje Suhega vrha v jugovzhodnem boku Hrušiškega pokrova (sl. 1, b) se po mehanizmu razlikuje od pobočnih zdrsov v pasu velikih gravitacijskih pojavov $\mathrm{v}$ jugovzhodnem boku Trnovskega pokrova (sl. 1, a) ter v čelih Trnovskega, Hrušiškega in Snežniškega pokrova (sl. 1).

Gravitacijsko območje Suhega vrha (sl. 1, b) je nastalo zaradi dviga antiforme v čelnem delu Hrušiškega pokrova in $\mathrm{s}$ tem tudi njene flišne podlage. Posledica tega so bili gravitacijski diferencialni premiki po sistemu subvertikalnih regionalnih razpok SSW-NNE. Kinematika teh premikov ustreza interni rotaciji in se razlikuje od mehanizma klasičnih pobočnih gravitacijskih pojavov v plaziščih pod Ubeljsko, Votlo in Rjavo steno.

Ubeljski zatrep je nastal zaradi razpada gravitacijskih struktur Suhega vrha na območju zatrepa, ki so jih degradirali klasični pobočni zdrsi in denudacijski procesi. Podobno usodo doživlja ohranjena gravitacijska struktura Suhega vrha za Votlo in Rjavo steno, ki ju izpodjedajo pobočni zdrsi plazišča Rjava stena. Proces denudacije se je tu pričel pozneje, ker se čelni rob Hrušiškega pokrova generalno umika proti severovzhodu.

Na območju Črnega školja in Malega Modrasovca (sl. 1, a; sl. 2) je izboklina flišne antiforme $\mathrm{v}$ čelnem delu in začelju Trnovskega pokrova komaj opazna, zato tu ni pogojev za nastanek diferencialnih premikov kot smo jih opisali v primeru nanoške antiforme (sl. 11), čeprav je tudi tu lepo razvit sistem regionalnih subvertikalnih razpok SSW-NNE. Obstajajo le klasični pobočni zdrsi plazišča Črni školj. V regionalnem smislu pa je pomembno, da leži obravnavana antiforma severozahodno od nanoške antiforme, zato je mogoče sklepati, da predstavlja njeno strukturno nadaljevanje ali pa prostorsko odmaknjeno ponovitev. Zaradi razlikovanja je smiselno uvesti pojem čavenska antiforma.

Velika rotacijska fosilna plazova v čelu Snežniškega pokrova; domnevni Petelinje mlake (sl. 1, c) in dokazani Ilirska Bistrica (sl. 1, d), kažeta na drugačne pogoje postnarivnega deformiranja kot v Hrušiškem in Trnovskem pokrovu.

Skupna značilnost vseh štirih izjemnih gravitacijskih pojavov je, da so povezani z deformacijami istrskega potisnega območja, ki so nastale po fazi dinarskega narivanja. Potisno območje 
Bistrica landslide (Fig. 1, d) indicate conditions of post-thrust deformation different from those in the Hrušica and Trnovo Nappes. A common feature of all four exceptional gravitational phenomena is their causal link to the deformations of the Istra Pushed Area that occurred after the Dinaric thrust phase. The Istra Pushed Area is a consequence of the Adriatic Microplate (Adria) movement towards the Dinarides - in our case, the movement of Istra and the offshore (and sea bed) of the Trieste Gulf. The Istran block is moving more intensely than the neighbouring Adria blocks SE of Istra. The process started in the Middle Miocene, and its activity (also recent) is manifested in many different ways.

Differences in the types of gravitational phenomena in the Hrušica and Trnovo Nappes Thrust Fronts on the one hand, and the Snežnik Nappe on the other, are also reflected in the type of postthrust deformation typical across the entire Istra Pushed Area, with particular differences in geomorphologic development. These will be presented in a following article, while this article serves as a basis for a discussion of these differences. je nasledek premikanja Jadranske mikroplošče (Adria) proti Dinaridom, v našem primeru premikanje Istre in podmorja Tržaškega zaliva. Ta blok se premika intenzivneje od sosednjih blokov Adrie jugovzhodno od Istre. Proces se je pričel v srednjem miocenu, njegova aktivnost pa se kaže na različne načine še danes.

Razlike med tipom gravitacijskih pojavov $\mathrm{v}$ območju čelnega dela Trnovskega in Hrušiškega pokrova na eni in Snežniškega pokrova na drugi strani, se odražajo tudi v tipu postnarivnih deformacij na celotnem ozemlju istrskega potisnega območja. Temu ustrezajo razlike v geomorfološkem razvoju, ki bodo opisane v drugem članku. Ta članek je osnova za razpravo o teh razlikah.

\section{References}

Buser, S., Grad, K. \& Pleničar, M. 1967: Osnovna geološka karta Jugoslavije 1:100.000, list Postojna $=$ The basic geological map of Yugoslavia 1: 100.000, sheet Postojna. Zvezni geološki zavod, Beograd.

Buser, S. 1976: Tektonska zgradba južnozahodne Slovenije = Tektonischer Aufbau SüdvestSloweniens. 8. jugosl. geol. kongres, Bled, 1.-5. okt. 1974, 3: 45-58.

Čar, J. \& Juren, A. 1980: Šmihelska tektonska krpa $=$ The klippe of Šmihel. Geologija 23/2: 279-283.

Čar, J. \& Šebela, S. 2001: Kraške značilnosti narivnega stika apnenec-dolomit pri Predjami = Karst characteristics of thrust contact limestone-dolomite near Predjama. Acta carsologica, 30/2: 141-156.

eVode, 2016. Medmrežje: http://www.evode.gov. si/index.php?id=87 (18.3.2021)

Kocjančič, M., Popit, T. \& Verbovšek, T. 2019: Gravitational sliding of the carbonate megablocks in Vipava Valley, SW Slovenia. Acta geographica Slovenica, 59/1: 7-22, Ljubljana. https://doi.org/10.3986/AGS.4851
Komac, M. \& Ribičič, M. 2008: Zemljevid verjetnosti pojavljanja zemeljskih plazov $\mathrm{v}$ Sloveniji 1: 250.000 = Landslide susceptibility map of Slovenia 1: 250.000. Geološki zavod Slovenije.

Limanowski, M. 1910: Wielkie przemieszczenia mas skalnych w Dynarydach kolo Postojny. Razpr. Wydz. matem. przyr. Akad. Umiej. III, 10, 109-171, Krakow.

Mlakar, I. 1969: Krovna zgradba idrijsko žirovskega ozemlja = Nappe structure of the Idrija - Žiri region. Geologija, 12: 5-72.

Placer, L. 2006: Strukturno-geološki nadzor z vidika varstva naravne dediščine na območju trase HC Razdrto-Vipava na odseku 0,00 $6,60 \mathrm{~km}$. Arhiv Geološkega zavoda Slovenije, Ljubljana.

Placer, L. \& Čar, J. 1974: Problem podzemeljske razvodnice Trnovskega gozda, Križne gore in Črnovrške planote $=$ The hydrological problematics of the High Karst between Idrijca and Vipava rivers (Trnovski gozd, Križna gora and the plateau of Črni vrh). Acta carsologica, 6: 81-93. 
Placer, L., Jež, J. \& Atanackov, J. 2008: Strukturni pogled na plaz Slano blato $=$ Structural aspect on the Slano blato landslide (Slovenia). Geologija, 51/2: 229-234. https:// doi.org/10.5475/geologija.2008.023

Placer, L., Vrabec, M. \& Celarc, B. 2010: The bases for understanding of the NW Dinarides and Istria Peninsula tectonics. Geologija, 53/1: 5586. https://doi.org/10.5474/geologija.2010.005

Placer, L. \& Jamšek, P. 2011: Ilirskobistriški fosilni plaz - mesto na plazu = The Ilirska Bistrica fossil landslide - The town on the landslide. Geologija, 54/2: 223-228. https:// doi.org/10.5474/geologija.2011.017

Popit, T. 2016: Mehanizmi transporta in sedimentacijski procesi kvartarnih pobočnih sedimentov na območju Rebrnic = Transport mechanisms and depositional processes of Quaternary slope deposits in Rebrnice area. Doktorska disertacija = Doctoral thesis. Univerza $\mathrm{v}$ Ljubljani, Fakulteta za gradbeništvo in geodezijo $\mathrm{v}$ Ljubljani in Naravoslovnotehniška fakulteta, Ljubljana: $341 \mathrm{p}$.

Popit, T. 2017: Origin of planation surfaces in the hinterland of Šumljak sedimentary bodies in Rebrnice (upper Vipava valley, SW Slovenia) = Nastanek reliefnih izravnav v zaledju sedimentnih teles Šumljak na Rebrnicah (zgornja Vipavska dolina, SW Slovenija). Geologija, 60/2: 297-307. https://doi.org/10.5474/ geologija.2017.021

Schmid, S., Bernoulli, D., Fügenschuh, B., Matenco, L., Schefer, S., Schuster, R., Tischler, M. \& Ustaszewski, K. 2008: The AlpineCarpathian-Dinaridic orogenic system: correlation and evolution of tectonic units. Swiss Journal of Geosciences, 101/1: 139-183. https://doi.org/10.1007/s00015-008-1247-3
Verbovšek, T., Teran, M., Zajc, M., Košir, A. \& Popit, T. 2017: Volume determination of the Selo landslide complex (SW Slovenia): integration of field mapping, Ground Penetrating Radar and GIS approach. Landslides, 14/3:1265-1274. https://doi.org/10.1007/ s10346-017-0815-X

Verbovšek, T., Popit, T. \& Kokalj, Ž. 2019: VAT method for visualization of mass movement features: an alternative to hillshaded DEM. Remote sensing, 11/24: 1-14. https://doi. org/10.3390/rs11242946

Vrabec, M., Pruner, P., Zupan Hajna, N., Mihevc, A. \& Bosak, P. 2018: Unraveling neotectonic vertical-axis rotations in the AdriaEurasia collision zone: paleomagnetic data from Pliocene-Quaternary cave sediments (Slovenia). In: Ustaszewski, K., Grützner, Ch. \& Navabpour, P. (eds.): TSK Jena 2018. 1st ed. Jena: Friedrich Schiller University Jena, Institute of Geological Sciences: $134 \mathrm{p}$.

Weber, J., Vrabec, M., Stopar, B. Pavlovčič Prešeren, P. \& Dixon, T. H. 2006: The PIVO2003 experiment: A GPS study of Istria peninsula and Adria microplate motion, and active tectonics in Slovenia. In: Pinter, N., Gyula, G., Weber, J., Stein, S. \& Medak, D. (eds.): The Adria Microplate: GPS Geodesy, Tectonics and Hazards, 305-320. Nato Science Series IV, Earth and Environmental Sciences, 61, Springer, Dordrecht. https://doi. org/10.1007/1-4020-4235-3_21

Weber, J., Vrabec, M., Pavlovčič Prešeren, P., Dixon, T., Jiang, Y. \& Stopar, M. 2010: GPSderived motion of the Adriatic microplate from Istria Peninsula and Po Plain sites, and geodynamic implications. Tectonophysics, 483/3-4: 214-222. https://doi.org/10.1016/j. tecto.2009.09.001 